\title{
CONTRACTING OUT OF FIDUCIARY DUTIES IN LLCS: DELAWARE WILL LEAD, BUT WILL ANYONE FOLLOW?
}

\author{
H. Justin Pace* \\ TABLE OF CONTENTS
}

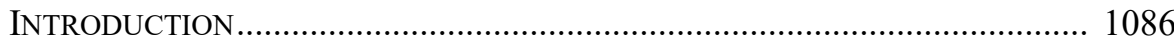

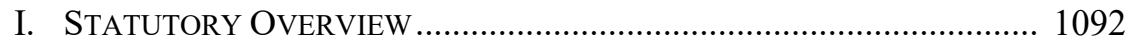

II. CASE LaW ANalysis of THE DElaware APPROACH ..................... 1095

A. Delaware Courts ................................................................ 1095

B. Case Law Tracking the Approach of Delaware Courts ............ 1098

1. Georgia Case Law .......................................................... 1098

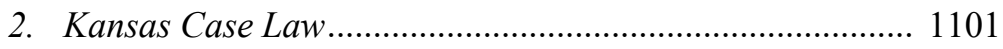

3. Louisiana Case Law...................................................... 1102

4. Massachusetts Case Law ................................................... 1103

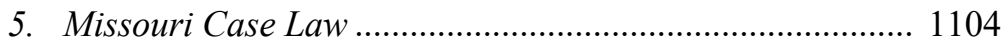

6. North Carolina Case Law ................................................. 1104

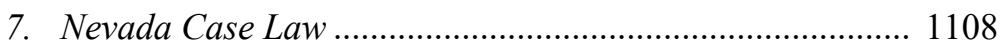

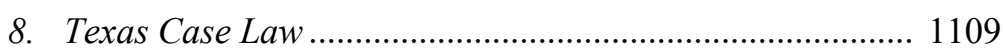

C. Case Law Departing from the Approach of Delaware Courts.. 1109

1. New York Case Law ......................................................... 1110

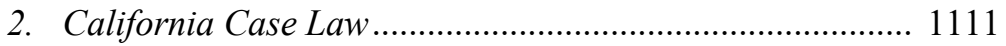

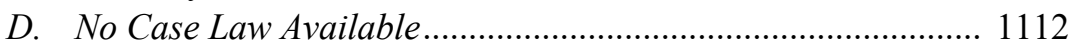

E. Final Analysis ........................................................................ 1113

III. ANALYSIS OF THE STATUTORY TEXT.............................................. 1114

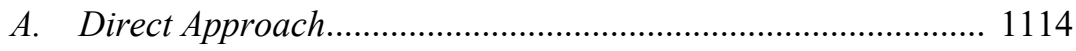

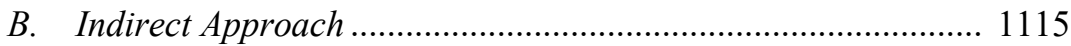

C. Direct Approach with No Mention of Elimination ..................... 1116

D. Direct Approach with Caveats ............................................... 1118

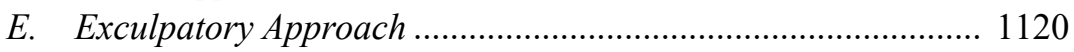

F. Final Analysis of the Statutory Text ....................................... 1120

IV. ANALYSIS Of LP CASE LAW ........................................................ 1121

A. Delaware Case Law ............................................................ 1121

* Visiting Assistant Professor, Florida State University College of Law. I thank professors Stephen Presser and Jim Lindgren for their insight and comments.

1085 
B. Maryland Case Law 1123

C. California Case Law 1124

D. Connecticut Case Law 1128

E. Massachusetts Case Law 1131

F. Final Analysis of LP Case Law 1133

V. MACRO IMPLICATIONS. 1133

A. Legislative Implications .... 1134

B. Judicial Implications 1135

VI. MicRo IMPLICATIONS 1139

A. Litigation Consequences 1139

B. Transaction Planning Considerations

\section{INTRODUCTION}

As a choice of entity, the limited liability company (LLC) shows great promise. It combines the flexibility of a contract-based form such as a partnership and the limited liability of a state-created form such as a corporation. The LLC ostensibly represents a triumph of freedom of contract in business law. The form is a product of statute, but the LLC is a creature of contract. The usefulness of the form, however, has been limited by continuing legal uncertainty. Despite the first LLC statute being passed in $1977,{ }^{1}$ the form is young relative to its competitors, and there remains a shocking paucity of case law.

This legal uncertainty has not prevented tremendous growth in the utilization of the LLC. Integral to early growth was a 1988 revenue ruling by the Internal Revenue Service that removed the requirement of personal liability for partnership tax status. ${ }^{2}$ By the mid-1990s, the LLC was supplanting the corporation as the form of choice for closely held firms. ${ }^{3}$ LLCs now account for more business filings than corporations in twenty-nine states. ${ }^{4}$

Statutory provisions in some states granting (or purporting to grant) members of LLCs the option to contract out of their fiduciary duties, typically through a written operating agreement, are testing the outer limits off this freedom of contract. Fiduciary duties are perhaps best understood as a response to the impossibility of contracting for all contingencies due to limited information and high transaction costs. ${ }^{5}$ Courts have responded to this inability to create

\footnotetext{
1 See Wyoming Limited Liability Company Act, ch. 158, 1977 Wyo. Sess. Laws 537.

2 Rev. Rul. 88-76, 1988-2 C.B. 360.

3 LARRY E. RibSteIn, THE Rise OF THE UnCORPORATION 119 (2010).

4 Sandra K. Miller, The Duty of Care in the LLC: Maintaining Accountability While Minimizing Judicial Interference, 87 NEB. L. REv. 125, 132 n.22 (2008) (citing Howard M. Friedman, The Silent LLC Revolution-The Social Cost of Academic Neglect, 38 CREIGHTON L. REV. 35, 37-38 (2004)).

5 See Frank H. Easterbrook \& Daniel R. Fischel, Contract and Fiduciary Duty, 36 J.L. \& ECON. 425, 426-27 (1993).
} 
express contractual provisions with implied provisions, ${ }^{6}$ but express provisions have governed since long before the rise of the highly flexible and contractbased LLC. ${ }^{7}$ This contractarian view has been challenged on a number of grounds,${ }^{8}$ including by a view that a fiduciary duty is a moral obligation ${ }^{9}$ and by arguments based on limits of cognition. ${ }^{10}$ This article is not intended to serve as a comprehensive rebuttal to criticism of the contractarian view. Rather, it quickly shows why the proper approach to the problem is economic and addresses the strongest economic arguments against allowing waiver.

As one of the critics of the contractarian view has aptly put it, "the overall social policy goal of business entity governance [is] to foster investor confidence while keeping transaction costs at a minimum." ${ }^{11}$ It is not by accident that the social policy goal is expressed in starkly economic terms. The "fiduciary" relationships discussed in this article are created by contracts of the usual sort, not as a function of a special relationship as in the traditional sense of a "fiduciary" relationship. ${ }^{12}$ The traditionalist-moralist school is off-base in pushing a traditional view of a fiduciary relationship — one based on a special relationship with specific duties - onto a different type of relationship lacking those hallmarks. Moreover, fiduciary duties make a poor vehicle for promoting social mores because remedies for a breach of fiduciary duty are available only within the LLC. If the concern is that LLCs are providing "important services affecting the public health and welfare," 13 then fiduciary duties are a particularly poor avenue to protect the public health and welfare.

Economic analysis of waiver of fiduciary duties - resting on decades of economic scholarship - has to start with a rebuttable presumption that private ordering - "self-regulation voluntarily undertaken by private parties" 14 - is sufficient. ${ }^{15}$ The second step is to examine evidence that private ordering is imper-

${ }^{6}$ See id. at 427.

7 See id. at 429 (giving several historical examples of waivers of certain fiduciary duties in diverse areas in which fiduciary duties have been applied).

8 See Sandra K. Miller, What Fiduciary Duties Should Apply to the LLC Manager After More than a Decade of Experimentation?, 32 J. CORP. L. 565, 575 (2007) (listing schools of thought on fiduciary duties, in addition to the contractarian school, as the "traditionalist/moralistic school," the "social science [or team production] school," the "game theory school," the "empirical school," and the "structural school.").

9 See, e.g., Miller, supra note 4, at 136-37 (describing the duty of care as performing an important function to "express community values").

10 See Melvin Aron Eisenberg, The Limits of Cognition and the Limits of Contract, 47 STAN. L. REV. 211, 249-51 (1995).

11 Miller, supra note 4, at 170-71.

12 For example, a trustee-beneficiary, conservator-ward, lawyer-client, or executor-legatee relationship.

13 Miller, supra note 4, at 128.

14 Niva Elkin-Koren, What Contracts Cannot Do: The Limits of Private Ordering in Facilitating a Creative Commons, 74 FordHAM L. REV. 375, 376 (2005).

15 See, e.g., Eisenberg, supra note 10, at 212 ("Bargains normally create value, enable the parties to plan their future conduct reliably, allocate commodities to their highest-valued us- 
fect. ${ }^{16}$ The strongest evidence of such can be grouped into two categories: the absence of a public market ${ }^{17}$ and limits of cognition. ${ }^{18}$ For example, bounded rationality would prevent the parties from identifying all of the possible circumstances to which a waiver of fiduciary duties would apply; the availability heuristic would lead parties to give undue weight to their relationship at the time the LLC was formed because that relationship is vivid, concrete, and instantiated; faulty telescopic faculties would tend to cause parties to give too much weight to the present benefits of their relationship as opposed to the future costs a waiver of fiduciary duties could lead to; and faulty risk estimation will lead the parties to underestimate the possible future costs of a waiver. ${ }^{19}$

Assuming without further inquiry that the above establishes that private ordering is imperfect - and it surely is - one cannot end the analysis there. To do so would be to fall prey to the Nirvana fallacy by comparing private ordering not to an actual alternative, but to an unattainable ideal. ${ }^{20}$ The next step, then, is to weigh the evidence of the costs of enforcing waivers against the costs of mandatory rules. ${ }^{21}$ The costs of mandatory fiduciary duties are considerable..$^{22}$ Litigation is a very costly avenue for recourse. ${ }^{23}$ Indeed, waiver may represent an understanding that recourse by litigation would be cost prohibitive. Managers make poor risk-bearers. ${ }^{24}$ Mandatory rules impose liability for acts that are

es, and best distribute the factors of production ...." (citing Melvin Aron Eisenberg, The Bargain Principle and Its Limits, 95 HARV. L. ReV. 741, 743-47 (1982))).

${ }^{16}$ See, e.g., Henry N. Butler \& Larry E. Ribstein, Opting Out of Fiduciary Duties: A Response to the Anti-Contractarians, 65 WASH. L. REV. 1, 64 (1990) ("[T]he approach throughout the law of contract is to presume in favor of private ordering until some type of market failure can be shown.").

17 See, e.g., Miller, supra note 4, at 174 ("Factors that work either singly or in combination to create opportunities for abuse in the absence of a public market include: 1) domination by a controlling owner in the management of the firm or in developing its operating agreement; 2 ) the separation of ownership and managerial control; 3) vulnerability resulting from the illiquid nature of the investment; and/or 4) decreased transparency and accountability resulting from reduced requirements concerning financial reporting and internal controls.").

18 See, e.g., Eisenberg, supra note 10.

19 See id. at 220-25 (discussing limitations on cognition); id. at 249-51 (applying those limitations to the waiver question).

20 See Harold Demsetz, Information and Efficiency: Another Viewpoint, 12 J.L. \& Econ. 1, 1 (1969); see also Butler \& Ribstein, supra note 16, at 62.

21 After all, delegation to an agent is always a question of a tradeoff between the "inevitable costs of delegating power to agents ... [and] the benefits of doing so." Butler \& Ribstein, supra note 16 , at 44 .

${ }^{22}$ See id. at 53-59; see also Miller, supra note 4, at 177 (recognizing "mandatory fiduciary duties are generally criticized for increasing costs").

23 See Butler \& Ribstein, supra note 16, at 29-30 ("[F]iduciary duties . . . expose the corporation to costly litigation."); Miller, supra note 4, at 138 (recognizing it is not "practical to seek judicial intervention whenever a manager's performance dips below the expected norm"); Miller, supra note 8, at 571 (recognizing the legal system "imposes astronomical legal fees and sky-rocketing legal judgments").

${ }^{24}$ Butler \& Ribstein, supra note 16, at 29-30, 53-54 (noting that managers are poor riskbearers in part because, unlike shareholders, they cannot "reduce the risk by diversification). 
not intentionally harmful and for acts that do not benefit the members or managers. ${ }^{25}$ The alternatives to allowing waiver do not give businesspeople the certainty they seek because almost all proposed alternatives allow some modification of fiduciary duties and many treat judicial discretion in enforcement as a feature, not a bug. ${ }^{26}$ Restricting waiver of fiduciary duties intrudes on the sensitive business decision of allocating managers time among myriad tasks. ${ }^{27}$

Judges lack expertise, ${ }^{28}$ information, ${ }^{29}$ and motivation (money at stake) compared to the businesspeople who formed the LLC and agreed to the operating agreement. Moreover, judges (and the proponents of approaches that put discretion in judicial hands) are subject to cognitive limits of their own. An actor will only gather and process information until the marginal costs of doing so equal the marginal returns. ${ }^{30}$ With a major return for a judge being the ruling surviving appeal, judges have only limited incentives to heavily invest their most precious asset - their time-in understanding the underlying issues and the relationship of the parties at the time the agreement was made. ${ }^{31}$

There is a robust body of research showing that "as a systematic matter, people are unrealistically optimistic." 32 Here it is not judges, but rather scholars who display undue optimism; recommendations for restrictions on waiver of fiduciary duties, particularly those that call for greater judicial scrutiny, underestimate the risk and cost of judicial error. The availability and representativeness heuristics lead decision-makers to judge the probability of an event "on the basis of comparable data and scenarios that are readily available to [the decision-maker's] memory or imagination" and to "systematically and erroneously view unduly small samples as representative." ${ }^{33}$ Contracts are performed 95 percent or more of the time, ${ }^{34}$ but judges only see agreements that have failed in some way. Accordingly, it is likely that judges overestimate the likelihood that a waiver will be exploited by an opportunistic party. Further, it is dangerous to draw any conclusions about parties' state of mind at the time the LLC

25 Id. at 53.

${ }^{26}$ See, e.g., id. at 62 (criticizing a recommendation for a four-factor judicial inquiry before enforcing opt-out); Miller, supra note 4, at 140 (criticizing an approach that "fails to permit the type of fine-tuning that may lead to more judicial scrutiny when there are passive investors and less judicial scrutiny when all partners participate"); Miller, supra note 8, at 600 (recommending a mandatory "core" of duties that "are not exhaustive or exclusive").

27 See Butler \& Ribstein, supra note 16, at 54.

28 See id. at 56.

29 See id. at 30 ("Because the parties usually cannot and do not specify the entire contract in their promise, the promise is only a 'fragment' of the entire understanding between the parties.").

30 Eisenberg, supra note 10, at 214-15 (citing George J. Stigler, The Economics of Information, 69 J. POL. SCI. 213 (1961)).

31 See, e.g., Stephen J. Choi et al., What Do Federal District Judges Want? An Analysis of Publications, Citations, and Reversals, 28 J.L. ECON. \& ORG. 518, 519 n.1 (2012).

32 Eisenberg, supra note 10, at 216-18.

33 Id. at 220-22.

34 See id. at 227. 
was formed or even about how often operating agreements with waivers of fiduciary duty go sour. Most business efforts using an LLC as a vehicle do not lead to disputes, most of those disputes do not lead to litigation, and most litigation ends with settlement, not a judicial opinion.

Perhaps most importantly, the costs of a waiver of fiduciary duty, to the extent they exist, are borne entirely or almost entirely by the parties who freely entered into the agreement. ${ }^{35}$ Concerns about limits on cognition are similarly blunted by the fact that those limits apply to all parties to the agreement.

Economic and broader normative debates aside, given that the controlling statute for each case discussed herein allows parties to in some way reduce, modify, or redefine their fiduciary duties, the analysis is properly first one of contractual and statutory interpretation. A reviewing court should begin its analysis by looking to the applicable statute for statutorily defined fiduciary duties and limitations on the modification of those duties. The court should then determine if the action allegedly leading to breach of fiduciary duty falls within the fiduciary duties of the members as defined by the operating agreement. If the action does not violate a fiduciary duty established by the operating agreement or fall outside of carve-outs from fiduciary duties in the operating agreement (i.e., it is not a breach of contract), then the only remaining question for the court is whether the implied covenant of good faith and fair dealing or another contract doctrine was violated.

A number of valid business reasons exist for parties to contract out of fiduciary duties. A waiver of the duty of loyalty may be necessary to recruit a member already participating in a business that could be construed as competing. In an area of substantial uncertainty ${ }^{36}$ parties can provide a more precise definition of their fiduciary duties. Tailored fiduciary duties can also be a very useful tool to socially conscious entrepreneurs. A waiver can help protect a member engaged in a number of intricate, intertwined business dealings. Tailored fiduciary duties can be used to in effect cleanse planned related-party transactions ex ante. This article will argue that courts in states allowing the waiver of fiduciary duty should enforce those waivers so that LLC members may benefit from the above.

35 See Butler \& Ribstein, supra note 16, at 49-50 ("[E]ven if new types of contract terms would impose new information and litigation costs, this does not make a case for mandatory limitation of contract terms because the costs of innovation are internalized. Unless the benefits of innovative terms outweigh the costs, investors will simply refrain from investing in firms with new contract terms if information costs have impeded rapid discounting of information into price or if there is an increased potential for costly litigation." (footnote omitted)).

36 See Thomas M. Madden, Do Fiduciary Duties of Managers and Members of Limited Liability Companies Exist As with Majority Shareholders of Closely Held Corporations?, 12 DUQ. BUS. L.J. 211, 214-15 (2010) (positing the law around fiduciary duties in "five major states"-Delaware, Massachusetts, California, New York, and Illinois-is much less clear for LLCs than for corporations). 
LLC statutes offer far greater ability to contract out of fiduciary duties than partnership statutes that once would have covered the same types of business entities. Ribstein and Keatinge's treatise on LLCs identifies five approaches to contracting out of fiduciary duties. ${ }^{37}$ Of these, the approach taken in the Delaware statute is by far the most popular, rivaled only by the approach of the 1996 Uniform Limited Liability Company Act (ULLCA). ${ }^{38}$ Twenty-five other states have adopted the Delaware approach. These include both major LLC states such as Nevada and Delaware, ${ }^{39}$ and major commercial states such as Texas and New York (and until recently, California). ${ }^{40}$ The Delaware approach allows for very broad freedom of contract in contracting out of fiduciary duties (outside of the implied duties of good faith and fair dealing inherent in all contracts) ${ }^{41}$

While it is unsurprising that many states would look to Delaware for business association law given the leading role it has traditionally played, it is surprising that those states would adopt such a permissive approach to this issue. Other states do not have the same unique incentives as Delaware to meet the changing needs of business associations. ${ }^{42}$ This article will argue that despite the categorization of these states with Delaware, by and large the enforceability of waivers of fiduciary duties remains very much in question in most of those states due to negative LLC case law, variations in the statutory text of individual states, and negative limited partnership (LP) law. Courts in particular can be expected to cling tightly to the traditional conception of fiduciary duties rooted in equity, despite their questionable utility to modern, contractual business associations formed by sophisticated parties and statutory direction to the contrary notwithstanding. Courts will also continue to show a tenuous understanding of the LLC as a distinct entity form. ${ }^{43}$ A recurring theme throughout this article is courts performing, at best, a limited statutory analysis in determining wheth-

37 See 1 Larry E. Ribstein \& Robert R. Keatinge, Ribstein and Keatinge on Limited LIABILITY COMPANIES app. 9-6 (2015) (tabulated statutory provisions).

38 See Unif. Ltd. Liab. Co. ACt § 103(b) (Unif. Law Comm’n 1996).

39 There were 47,726 LLC filings in Delaware in 2002, more than in any other state. There were 16,663 LLC filings in Nevada, more than some states with over twice its population. Friedman, supra note 4, at 92-93.

${ }^{40}$ California, Texas, and New York are the three largest states by gross domestic product as of 2008. Caitlin E. Coakley et al., U.S. Bureau of Econ. Analysis, Gross Domestic Product by State: Advance Statistics for 2008 and Revised Statistics for 2005-2007, 89 SuRV. CURRENT Bus., June 2009, at 62, 89.

41 See Del. Code ANN. tit. 6, § 18-1101(e) (2016) ("[A] limited liability company [operating] agreement may not limit or eliminate liability for any act or omission that constitutes a bad faith violation of the implied contractual covenant of good faith and fair dealing.").

42 See, e.g., Lawrence A. Hamermesh, The Policy Foundations of Delaware Corporate Law, 106 Colum. L. Rev. 1749, 1755-59 (2006); Roberta Romano, Law As a Product: Some Pieces of the Incorporation Puzzle, 1 J.L. ECON. \& ORG. 225 (1985).

43 A LexisNexis search for "limited liability corporation" performed on February 17, 2015, returned 5,987 cases. 
er a waiver is enforceable. We also see a reluctance by the courts to treat sophisticated parties as such.

Part I of this article provides a statutory overview of the five major approaches. Sub-approaches grouped with the "Delaware approach" are also discussed. Part II analyzes relevant LLC case law applying the law of states ostensibly adopting the Delaware approach. Given the paucity of LLC case law, Part III analyzes the statutory text of variations of the Delaware approach. Part IV attempts to make inferences where case law is insufficient through analysis of relevant LP case law. Part V surveys the macro (legislative and judicial) implications and Part VI will survey the micro (litigation and transaction planning) implications of the state of the case law and statutes. This article calls for courts to enforce operating agreements relieving members of fiduciary duties and for state legislatures to provide greater statutory clarity on the matter. ${ }^{44}$

\section{STATUTORY OVERVIEW}

Ribstein and Keatinge sort statutory provisions dealing with contracting out of fiduciary duties into five categories. ${ }^{45}$ The most popular approach, and the approach that is the primary focus of this article, gives very broad power to contract out of fiduciary duties in the operating agreement (the "Delaware approach"). Ribstein and Keatinge identify twenty-six states as having adopted this approach, including Delaware. ${ }^{46}$ The Idaho state legislature adopted the ULLCA effective July 1, 2017, ${ }^{47}$ and Idaho state law will not be discussed in this article. Although California repealed its LLC Act and adopted the ULLCA approach, ${ }^{48}$ California law will be addressed because the change was only effective as of January 1, 2014, and by its own terms the new act does not govern

44 This article will not address a number of outstanding issues tangentially related to waiver of fiduciary duties. Issues outside of the scope of this article include: exactly what default fiduciary duties apply in a given state; the fiduciary duties owed by non-managing members of an LLC as opposed to managers in a manager-managed LLC; the fiduciary duties owed to other members of an LLC as opposed to owed to the LLC itself; any fiduciary duties that may be owed by a controlling member to the non-controlling members; choice of law; and standing to sue another member of the LLC directly rather than through a derivative suit and other standing issues. This article will also not address fiduciary duties vis a vis third parties or what effect waiver of fiduciary duties may have on piercing the corporate veil.

45 See 1 RiBSTEIN \& KeATINGE, supra note 37.

46 Id. (categorizing Alabama, Arkansas, California, Colorado, Connecticut, Delaware, Georgia, Idaho, Kansas, Kentucky, Louisiana, Maine, Maryland, Massachusetts, Michigan, Mississippi, Missouri, North Carolina, Nevada, New Hampshire, New Jersey, New Mexico, New York, Texas, Washington, and Wisconsin under this approach).

47 IDAHO CODE $§ 30-6-110$ (2016) (repealed effective July 1, 2017).

48 See CB Richard Ellis, Inc. v. Terra Nostra Consultants, 178 Cal. Rptr. 3d 640, 644 n.4 (Cal. Ct. App. 2014) ("The California Revised Uniform Limited Liability Company Act (§ 17701.01 et seq., added by Stats.2012, ch. 419, § 20) took effect on January 1, 2014, supplanting the Beverly-Killea Limited Liability Company Act (former $\S 17000$ et seq., repealed by Stats.2012, ch. 419, § 19).”). 
contracts entered into before that date ${ }^{49}$ New Jersey follows the ULLCA "manifestly unreasonable" approach and will not be covered. ${ }^{50}$ Part III examines in greater depth variances between the LLC statutes of those twenty-four states.

The second most popular approach, that of the ULLCA, states that members may not eliminate the loyalty duty or good faith obligation or unreasonably reduce duty of care, but may identify activities that do not violate the duty of loyalty if not manifestly unreasonable, and specify the vote necessary to approve the act or transaction that otherwise would violate the duty of loyalty. ${ }^{51}$ There are also two minor approaches. Several jurisdictions limit the power to waive managers' liability for a breach of the duty of care. ${ }^{52} \mathrm{~A}$ handful of jurisdictions have neglected to provide any provision for the waiver of fiduciary duties. ${ }^{53}$

Given the potential for each jurisdiction to have a unique text, the approaches can bleed into each other, and, due to the variations in the statutory text under the Delaware approach, some of the states that are included in the Delaware approach group may more sensibly fit in another category.

Twenty-four states ostensibly follow the Delaware approach,,${ }^{54}$ but the statutory text of the applicable provision(s) varies among those states. The statutory approaches can be divided into five sub-approaches: (1) directly providing for the waiver; ${ }^{55}(2)$ indirectly providing for the waiver; ${ }^{56}$ (3) directly providing for the waiver but making no mention of elimination of fiduciary duties ${ }^{57}$ (4)

49 CAL. CoRP. Code $§ 17713.04$ (b) (West Supp. 2016) ("[T] his title applies only to ... contracts entered into by the limited liability company or by the members or managers of the limited liability company, on or after January 1,2014 . The prior law governs all ... contracts entered into by the limited liability company or by the members or managers of the limited liability company, prior to January $1,2014 . ")$.

50 See N.J. Stat. AnN. § 42:2C-11 (West Supp. 2015).

51 Unif. Ltd. Liab. Co. ACT § 103(b) (Unif. LAW COMM’N 1996).

52 See 1 RibSTEIn \& KeATINGE, supra note 37.

53 Id.

54 Those states are Alabama, Arkansas, California (repealed, but not retroactively), Colorado, Connecticut, Delaware, Georgia, Kansas, Kentucky, Louisiana, Maine, Maryland, Massachusetts, Michigan, Mississippi, Missouri, North Carolina, Nevada, New Hampshire, New Mexico, New York, Texas, Washington, and Wisconsin.

55 See Ala. Code § 10A-5A-1.08(b)(1) (Supp. 2015); Del. Code AnN. tit. 6, § 18-1101 (2016); Nev. Rev. Stat. § 86.286(5) (2013); N.H. REv. Stat. ANN. § 304-C:107 (2015).

56 See ARK. Code ANN. § 4-32-402 (West 2004) (laying out fiduciary duties with the caveat "[u]nless otherwise provided in an operating agreement"); N.M. STAT. ANN. § 53-19-16 (West 2003) (setting duty of care to a "gross negligence or willful misconduct" standard "unless otherwise provided by ... an operating agreement").

57 See KAn. STAT. ANN. § 17-76,134(c) (West 2014) (replacing the previous language that “[t]he member's or manager's or other person's duties and liabilities may be expanded or restricted by provisions in an operating agreement" with language directly allowing elimination of fiduciary duties in the operating agreement, pursuant to 2014 Kan. Sess. Laws 224); MASS. GEN. LAWS ANN. ch. 156C, § 63(b) (West 2005) ("To the extent that . . . a member or manager has duties, including fiduciary duties, and liabilities relating thereto . . . the member's or manager's duties and liabilities may be expanded or restricted by provisions in the operating agreement.”); Mo. ANN. STAT. § 347.088 (West 2015) (“The member's, manager's 
directly providing for the waiver but with caveats, ${ }^{58}$ and (5) only providing that the operating agreement may eliminate or limit liability for monetary damages for breach of duty (exculpatory approach). ${ }^{59}$

There is substantial variation from state to state. Some states carve out duties that cannot be waived. ${ }^{60}$ Some states provide for fiduciary duties in their

or other person's duties and liabilities may be expanded or restricted by provision in the operating agreement.”); Tex. Bus. ORgs. Code ANN. § 101.401 (West 2012) (“The [operating] agreement of a limited liability company may expand or restrict any duties, including fiduciary duties, and related liabilities that a member, manager, officer, or other person has to the company or to a member or manager of the company.”); CAL. CORP. CODE app. $§ 17005(\mathrm{~d})$ (West 2014) (repealed 2014).

58 See Colo. Rev. Stat. AnN. § 7-80-108(1.5) (West 2006) ("To the extent that a member or manager or other person that is a party to, or is otherwise bound by, the operating agreement has duties, including, but not limited to, fiduciary duties, to a limited liability company or to another member, manager, or other person that is a party to or is otherwise bound by an operating agreement, the duties of such member, manager, or other person may be restricted or eliminated by provisions in the operating agreement, as long as any such provision is not manifestly unreasonable." (emphasis added)); GA. CODE ANN. § 14-11-305(4)(A) (West 2003) ("To the extent that ... a member or manager has duties (including fiduciary duties) and liabilities relating thereto to a limited liability company or to another member or manager: (A) The member's or manager's duties and liabilities may be expanded, restricted, or eliminated by provisions in ... a written operating agreement; provided, however, that no such provision shall eliminate or limit the liability of a member or manager: (i) For intentional misconduct or a knowing violation of law; or (ii) For any transaction for which the person received a personal benefit in violation or breach of any provision of a written operating agreement ....”); Miss. CodE ANN. § 79-29-123(4) (2016); Wash. Rev. CodE $\S 25.15 .038(6)(2016)$.

59 See Conn. Gen. StAT. AnN. § 34-143(1) (West 2015) (“An operating agreement may ... [e]liminate or limit the personal liability of a member or manager for monetary damages for breach of any [fiduciary] duty provided for in section 34-141 . ..."); KY. REV. STAT. ANN. $\S 275.180$ (1) (West 2006) ("A written operating agreement may ... [e]liminate or limit the personal liability of a member or manager for monetary damages for breach of any [fiduciary] duty provided for in [section] 275.170 . ...”); LA. STAT. ANN. § 12:1315 (2010); Mich. COMP. LAWS ANN. § 450.4407 (West 2011); N.Y. LTD. Liab. Co. LAW § 417(a) (McKinney 2016); N.C. Gen. StAT. ANN. § 57C-3-32(a)-(b) (West 2011) (repealed 2014) ("Subject to subsection (b) of this section, ... a written operating agreement may: (1) Eliminate or limit the personal liability of a manager, director, or executive for monetary damages for breach of any [fiduciary] duty provided for in [section] $57 \mathrm{C}-3-22 \ldots$. No provision permitted under subsection (a) of this section shall limit, eliminate, or indemnify against the liability of a manager, director, or executive for (i) acts or omissions that the manager, director, or executive knew at the time of the acts or omissions were clearly in conflict with the interests of the limited liability company, (ii) any transaction from which the manager, director, or executive derived an improper personal benefit ....”) North Carolina's chapter 57C was repealed in 2014 and replaced with a rather more confusing wording that appears to indirectly allow waiver in chapter 57D.

60 See, e.g., GA. CODE ANN. § 14-11-305(4) (2003) ("[N]o such provision shall eliminate or limit the liability of a member or manager: (i) For intentional misconduct or a knowing violation of law; or (ii) For any transaction for which the person received a personal benefit in violation or breach of any provision of a written operating agreement ...."); N.C. GEN. STAT. ANN. §57C-3-32(b)(ii) (West 2011) (repealed 2014) ("No provision permitted under subsection (a) of this section shall limit, eliminate, or indemnify against the liability of a manager, director, or executive for ... (ii) any transaction from which the manager, director, or executive derived an improper personal benefit."). 
LLC statutes ${ }^{61}$ and some import fiduciary duties from partnership law. ${ }^{62}$ There remains some question of exactly what fiduciary duties apply in some states. ${ }^{63}$

\section{CASE LAW ANALYSis OF THE DELAWARE APPROACH}

Case law in states following the Delaware approach is marked by a contrast between a trove of precedent in Delaware and a paucity of precedent in the rest of the states. Part A analyzes decisions by the Delaware courts. Part B analyzes decisions by courts in other states tracking the decisions of the Delaware courts. Part $\mathrm{C}$ analyzes decisions by courts in other states that fail to follow the approach of the Delaware decisions. Part D discusses states with no case law available, and Part E provides a final analysis.

\section{A. Delaware Courts}

Delaware courts have addressed the enforceability of a waiver of fiduciary duties in the LLC context more often than courts in any other state. The Delaware Court of Chancery has certainly addressed the issue far more often than any other individual court. In general, Delaware state courts have been very open to enforcing waivers of the fiduciary duties of LLC members. ${ }^{64}$ The Del-

61 See, e.g., N.C. GEN. STAT. ANN. § 57C-3-22 (West 2011) (repealed 2014).

62 See, e.g., CAL. CORP. CODE app. § 17153 (West 2014) (repealed 2014).

63 See Madden, supra note 36, at 213 (identifying the roots of uncertainty in LLC fiduciary duties in ambiguous corporation law decisions).

${ }^{64}$ See, e.g., Wood v. Baum, 953 A.2d 136, 140-42 (Del. 2008) (holding a waiver of liability for any action not fraudulent, illegal, or in bad faith required the plaintiff to plead such a claim with particularized facts); Dawson v. Pittco Capital Partners, L.P., No. 3148-VCN, 2012 WL 1564805, at *26-28 (Del. Ch. Apr. 30, 2012) (relying on Fisk Ventures, L.L.C. v. Segal in holding that LLC agreement waived all fiduciary duties); Related Westpac L.L.C. v. JER Snowmass L.L.C., No. 5001-VCS, 2010 WL 2929708, at*8 (Del. Ch. July 23, 2010) (refusing to examine reasonableness of decisions because operating agreement removed any reasonableness qualification on the member's power to make those decisions); Fisk Ventures, L.L.C. v. Segal, No. 3017-CC, 2008 WL 1961156, at *9-10 (Del. Ch. May 7, 2008) (enforcing operating agreement with a provision disclaiming any fiduciary duties not set forth expressly within the operating agreement and providing for duties in no other provision); Flight Options Int'l, Inc. v. Flight Options, L.L.C., No. 1459-N, 2005 WL 6799224, at *7 (Del. Ch. July 11, 2005) (interpreting provision requiring transactions between the LLC and its majority owner meet an "arms' length" standard to trump a provision setting broad fiduciary duties). But see Paige Capital Mgmt., L.L.C. v. Lerner Master Fund, L.L.C., No. 5502-CS, 2011 WL 3505355, at *31-32 (Del. Ch. Aug. 8, 2011) (holding "sole discretion" clause not a broad waiver of fiduciary duty); In re Atlas Energy Res., L.L.C., No. 4589VCN, 2010 WL 4273122, at*8 (Del. Ch. Oct. 28, 2010) (holding provision inapplicable where it referenced only conflicts of interest with affiliates, not the minority unitholders at issue); Vila v. BVWebTies L.L.C., No. 4308-VCS, 2010 WL 3866098, at*12 (Del. Ch. Oct. 1, 2010) (holding that traditional corporation law principles did not trump an explicit provision of the operating agreement); Kelly v. Blum, No. 4516-VCP, 2010 WL 629850, at *10 12 (Del. Ch. Feb. 24, 2010) (enforcing an exculpatory provision but holding that it did not serve as a waiver of fiduciary duties); Bay Ctr. Apartments Owner, L.L.C. v. Emery Bay PKI, L.L.C., No. 3658-VCS, 2009 WL 1124451, *at 8-9 (Del. Ch. Apr. 20, 2009) (interpreting contract as providing no waiver); Solar Cells, Inc. v. True N. Partners, L.L.C., No. 
aware federal courts and courts in other states have also enforced waivers under Delaware law. ${ }^{65}$ This openness to contracting around default rules is not limited to fiduciary duties-Delaware courts have enforced other types of waivers found in LLC operating agreements. ${ }^{66}$

The Delaware Supreme Court addressed the enforceability of a waiver of fiduciary duty for LLC members in Wood v. Baum. ${ }^{67} \mathrm{MME}$ was an investment house organized as a Delaware LLC. ${ }^{68}$ Paddy Wood, the plaintiff, sued the defendants, the directors of MME's board, for a number of separate breaches of fiduciary duty. ${ }^{69}$ The LLC's operating agreement contained a provision exculpating the directors from liability "except in cases of fraudulent or illegal conduct." 70 Thus, the plaintiff was required to plead a non-exculpated claim, in this case including "particularized facts that demonstrate that the directors acted with scienter" due to the nature of the carve-outs contained in the waiver. ${ }^{71}$ The plaintiff had failed to do so, and the Delaware Supreme Court affirmed dismissal of her complaint. ${ }^{72}$

The case best indicative of how open the Delaware courts are to waivers of fiduciary duty is Fisk Ventures, L.L.C. v. Segal. ${ }^{73}$ Dr. Segal formed an LLC,

Civ.A. 19477, 2002 WL 749163, at *4 (Del. Ch. Apr. 25, 2002) (finding a waiver of liability from any conflict of interest did not prevent injunctive relief).

65 See, e.g., In re ALH Holdings L.L.C., 675 F. Supp. 2d 462, 478 (D. Del. 2009) (enforcing provision of operating agreement limiting the standard for breaches of fiduciary duty to instances of fraud, criminal action, bad faith, and gross negligence); In re CLK Energy Partners, L.L.C., No. 09-05042, 2010 WL 1930065, at*8-9 (Bankr. W.D. La. May 12, 2010) (rejecting claim for breach of fiduciary duty by the trustee on the basis that it did not reference the operating agreement and thus did not give fair notice); Westbard Apartments, L.L.C. v. Westwood Joint Venture, L.L.C., 954 A.2d 470, 479-82 (Md. Ct. Spec. App. 2007) (reversing lower court decision finding sections of the operating agreement together constituting a waiver as ambiguous). But see In re Reg'l Diagnostics, L.L.C., 372 B.R. 3, 29 (Bankr. N.D. Ohio 2007) (interpreting a waiver limiting breach of fiduciary duties to instances of bad faith as not affecting the duty of loyalty).

${ }^{66}$ See, e.g., Elf Atochem N. Am., Inc. v. Jaffari, 727 A.2d 286, 288-89, 292 (Del. 1999) (holding the Court of Chancery lacked jurisdiction due to a clause requiring all disputes to be arbitrated in California); R \& R Capital, L.L.C. v. Buck \& Doe Run Valley Farms, L.L.C., No. 3803-CC, 2008 WL 3846318, at *4-7 (Del. Ch. Aug. 19, 2008) (enforcing a waiver of the right to force dissolution); Douzinas v. Am. Bureau of Shipping, Inc., 888 A.2d 1146, 1148-49 (Del. Ch. 2006) (relying on Elf Atochem in enforcing an arbitration provision mandating arbitration of a claim addressing the validity of a waiver of fiduciary duty); see also Dillon v. Typaldos, 2006 WL 1381625, *11-12 (N.J. Super. Ct. Ch. Div. 2006) (enforcing mandatory arbitration provision under Delaware law).

67 See Wood, 953 A.2d 136.

68 Id. at 138.

69 See id. at 139.

${ }_{70} \mathrm{Id}$.

${ }^{71} \mathrm{Id}$. at 141.

72 Id. at 141, 144.

73 See Fisk Ventures, L.L.C. v. Segal, No. 3017-CC, 2008 WL 1961156 (Del. Ch. May 7, 2008). 
Gentrix, ${ }^{74}$ with Dr. Johnson to develop and market biomedical technology. ${ }^{75}$ Dr. Segal contributed patents acquired during his postdoctoral fellowship, while Dr. Johnson served as the deep pocket. ${ }^{76}$ Dr. Johnson and Fisk Ventures, an entity he controlled, eventually came to control three of five seats on the Gentrix board, but due to a requirement in the operating agreement that 75 percent of directors approve most actions, Dr. Segal was able to maintain an effective veto. ${ }^{77}$ Initial financing proved insufficient, and faced with Dr. Johnson's unwillingness to contribute further capital, Dr. Segal asked that the "Put Rights" of the class B investors be suspended in order to make the company more attractive to outside investors. ${ }^{78}$ Dr. Johnson, who owned or controlled most of the class B interest, refused. ${ }^{79}$ Dr. Segal was unable to secure new investors, and Dr. Johnson and the other class B interest holders exercised a provision of the operating agreement allowing them to remove him as CEO ${ }^{80}$ With the two sides unable to agree on a future course and the company out of operating cash, Fisk Ventures (controlled by Dr. Johnson) brought suit to force dissolution of Gentrix. ${ }^{81}$

Dr. Segal made counterclaims against Fisk Ventures for breach of contract and fiduciary duties. ${ }^{82}$ There was one small problem with Dr. Segal's claimFisk Ventures owed no fiduciary duties to Gentrix under the operating agreement. The operating agreement expressly waived any fiduciary duties not expressly set forth elsewhere in the operating agreement. ${ }^{83}$ No other provision in the operating agreement created a fiduciary duty of any sort ${ }^{84}$ The court found this sufficient to reject Dr. Segal's counterclaim, although it did hedge by stating that even if the operating agreement did establish fiduciary duties, Dr. Segal did not allege facts sufficient to allow an inference of "gross negligence, willful misconduct, ... bad faith, or ... knowing[] violat[ion of] the law." 85 In its analysis of the breach of fiduciary duty claim, the court merely reiterated its earlier analysis of the breach of contract claim. There were no fiduciary duties to be violated.

74 Gentrix was initially formed as a Maryland LLC but was later moved to Delaware. Id. at $* 2$.

75 Id.

$76 I d$.

77 Id.

$78 I d$. at $* 3-4$.

79 Id. at $* 4$.

${ }^{80} I d$. at $* 4-5$.

81 Id. at $* 6$.

$82 \mathrm{Id}$.

${ }^{83}$ Id. at *9 ("No Member shall have any duty to any Member of the Company except as expressly set forth herein or in other written agreements.").

${ }^{84}$ Id. at *11 ("Pursuant to this provision, the Genitrix LLC Agreement eliminates fiduciary duties to the maximum extent permitted by law by flatly stating that members have no duties other than those expressly articulated in the Agreement. Because the Agreement does not expressly articulate fiduciary obligations, they are eliminated.").

85 Id. at $* 10$. 
Delaware courts have made a strong statement for the freedom of contract and the enforceability of waivers of fiduciary duties. While there may still be some questions around the edges, there is sufficient case law to be confident in the enforceability of a variety of waivers.

\section{B. Case Law Tracking the Approach of Delaware Courts}

Courts in six states - Georgia, Kansas, Massachusetts, North Carolina, Nevada, and Texas - have case law tracking the Delaware courts.

\section{Georgia Case Law}

The Georgia Court of Appeals addressed the issue of waiver of fiduciary duties in three cases, all decided in 2005 (three judges served on both the en banc panel for one of the cases and the three-judge panel for another). ${ }^{86}$ In the first case, Stoker v. Bellemeade, L.L.C., the Stokers and other investors formed several Georgia LLCs to develop real estate. ${ }^{87}$ The Stokers brought suit claiming that the other members breached their fiduciary duties by, among other things, usurping an LLC opportunity by developing other tracts of land ${ }^{88}$ Relying on the Georgia LLC Act, ${ }^{89}$ the court noted that members may restrict their fiduciary duties by contract in the operating agreement. ${ }^{90}$ The court interpreted the waiver provision in the operating agreement as giving the members free rein to participate in competing businesses. ${ }^{91}$ Thus, developing tracts of land not covered by the operating agreement did not breach any fiduciary duties. ${ }^{92}$

86 See Alimenta (USA), Inc. v. Oil Seed S., L.L.C., 622 S.E.2d 363, 365 (Ga. Ct. App. 2005); Stoker v. Bellemeade, L.L.C., 615 S.E.2d 1, 4 (Ga. Ct. App. 2005), rev'd in part on other grounds, 631 S.E.2d 693 (Ga. 2006).

87 Stoker, 615 S.E.2d at 4.

${ }^{88}$ Id. at 8-9.

89 See GA. CodE AnN. § 14-11-305 (West 2003).

90 Stoker, 615 S.E.2d at 9.

91 Id. at 9-10 ("The LLC operating agreements at issue ... contained the following provisions: ' $[\mathrm{N}]$ othing in this Agreement shall be deemed to restrict in any way the rights of any Member, or of any Affiliate of any Member, to conduct any other business or activity whatsoever, and no Member shall be accountable to the [LLC] or to any other Member with respect to that business or activity even if the business or activity competes with the [LLC's] business. The organization of the [LLC] shall be without prejudice to the Members' respective rights (or the rights of their respective Affiliates) to maintain, expand, or diversify such other interests and activities and to receive and enjoy profits or compensation therefrom. Each Member waives any rights the Member might otherwise have to share or participate in such other interests or activities of any other Member or Member's Affiliates.' These provisions make clear that, despite any duties described in the LLC Act that might have otherwise restrained a member from competing with the LLC, the members exercised the freedom granted by the LLC Act to restrict or eliminate those duties by contract and to engage in activities which competed with the LLC's business." ).

92 Id. at 10. 
Two judges on the Stoker panel dissented in part and concurred in part. ${ }^{93}$ The dissent took issue with the majority's interpretation of the "other business or activity" language from the waiver provision in the operating agreement. ${ }^{94}$ The dissent argued that because the operating agreement did not indicate which parcels of land it applied to, and because many of the parcels were not added to the individual LLCs until years after the operating agreement was signed, it was not clear whether the parcels in question should be included in the "business" of the LLC for the purpose of the waiver provision. ${ }^{95}$ Thus, there was an ambiguous question of fact that should have been put before the jury. ${ }^{96}$ Note that the dissent's critique was of the interpretation of the scope of a contract term, not of the enforceability of the waiver provision.

The decision in Alimenta (USA), Inc. v. Oil Seed South, L.L.C., soothed any concerns there might have been that the dissent in Stoker was a sign of hostility toward waivers of fiduciary duties. ${ }^{97}$ One of the judges from the Stoker dissent authored the opinion in Alimenta. ${ }^{98}$ Alimenta and Oil Seed formed a joint venture organized as a Georgia LLC to build a cottonseed oil plant. ${ }^{99}$ Alimenta gained control of the LLC when the price of cottonseed oil unexpectedly dropped by converting loans to capital contributions. ${ }^{100}$ Subsequently, it sold the LLC to a company in which it held a partial ownership stake. ${ }^{101}$ Alimenta then sued Oil Seed under the operating agreement for indemnification for 50 percent of its capital contributions. ${ }^{102}$

Oil Seed alleged in its counterclaim that Alimenta had breached its fiduciary duties by engaging in a self-dealing transaction without disclosing it to Oil Seed. ${ }^{103}$ The court, however, held that any contract terms more specific than the provisions of the LLC Act would prevail. ${ }^{104}$ The court then properly interpreted provisions granting Alimenta complete management control and allowing Alimenta to engage in conflict of interest transactions or compete with the LLC as waiving Alimenta's duty of loyalty to the LLC. ${ }^{105}$ Thus, the self-dealing trans-

93 See id. at 13 (Barnes, J., and Adams, J., dissenting in part and concurring in part).

94 Id. at 19.

95 Id.

96 Id. at $18,20$.

97 See Alimenta (USA), Inc. v. Oil Seed S., L.L.C., 622 S.E.2d 363, 365 (Ga. Ct. App. 2005).

98 Id. (Judge Barnes).

99 Id.

$100 \mathrm{Id}$.

101 Id.

102 Id.

103 Id. (relying on GA. CodE ANN. § 14-11-305(1) (West 2003)).

104 Id. at 367 (citing Tower Projects v. Marquis Tower, 598 S.E.2d 883 (Ga. Ct. App. 2004)).

105 Id. ("The contract provided that any member could engage in conflict of interest transactions, and that as manager, Alimenta was allowed to compete directly with Mid Georgia and had 'complete control of the management of the Company's business and affairs." "). 
action did not breach a fiduciary duty because the applicable duty had been waived.

The Georgia Court of Appeals enforced another limited waiver of the duty of loyalty in Ledford v. Smith. ${ }^{106}$ In Ledford, a carpet company (owned in part by eventual plaintiff Ledford) and a group of investors (including eventual defendant Smith) organized a Georgia LLC to sell carpet to the hospitality industry. ${ }^{107}$ In order to maintain control over who their business partners would be, the parties included provisions in the operating agreement giving the other parties a right of first refusal for the interest of a member desiring to sell. ${ }^{108}$ The operating agreement also contained a partial waiver of the duty of loyalty allowing members to participate in any business not directly competing with the LLC (with an exception carved out for Ledford's carpet company). ${ }^{109}$ The Smith cohort of investors, desiring to gain control of the LLC in order to sell it, exercised the mandatory put and call provision in the operating agreement and offered Ledford's company $\$ 3.5$ million (financed by an outside buyer) for its share of the LLC. ${ }^{110}$ Ledford's company chose to sell. ${ }^{111}$

Ledford sued Smith, et al., alleging that they breached their fiduciary duty of loyalty by failing to disclose that their offer was funded by a third party. ${ }^{112}$ The court held that the Smith cohort had no duty to disclose their negotiations with the third party because the negotiations were for financing. ${ }^{113}$ Entrance of a third party into the ownership group was not implicated so the right of first refusal provision was not triggered (by the time an actual offer was made the Smith group had full control of the LLC). ${ }^{114}$ The court also held that the negotiations with a third party did not violate the provision disallowing direct competition because it could not be construed as "competing" with the LLC. ${ }^{115}$

\footnotetext{
106 See Ledford v. Smith, 618 S.E.2d 627, 627 (Ga. Ct. App. 2005).

107 Id. at 630 .

108 Id.

109 Id. at 631 ("Paragraph 7.3 provided: 'Activities of Member and Affiliates. Notwithstanding the provisions of OCGA § 14-11-307 of the [Georgia Limited Liability Company] Act, the Members acknowledge and agree that the Members and their respective Affiliates are presently, or may become in the future, general partners of partnerships, managers of other limited liability companies, or associated in some other manner with other businesses. The Members and their respective Affiliates may engage in all such other business ventures, including without limitation ventures involving the purchase, sale and operation of other businesses, but no Active Member shall engage in businesses similar to the business of the Company by competing with the business of the Company while they are employed with the Company, except for business associations of Active Members with Vista Carpet Industries, LLC." ").

$110 I d$. at 632 .

111 Id.

$112 I d$. at 633.

113 Id.

114 Id. at 634.

$115 \mathrm{Id}$. at 635.
} 
Stoker, Alimenta, and Ledford together provide strong support for the enforceability of waivers of the duty of loyalty under the Georgia LLC Act. While no Georgia case has addressed the enforceability of a waiver of the duty of care, it is likely that a court interpreting the Georgia LLC Act will enforce waivers to their statutory limit. ${ }^{116}$

\section{Kansas Case Law}

Kansas courts have only addressed the enforceability of a fiduciary waiver provision in an LLC operating agreement in one case, Lynch Multimedia Corp. v. Carson Communications, L.L.C. ${ }^{117}$ Lynch, the plaintiff company, had formed a joint venture with a trust and a company, both controlled by Carson, an individual, for the purpose of operating cable television franchises. ${ }^{118}$ This joint venture was organized as a Kansas LLC, with the trust and the company as members and Carson as the president. ${ }^{119}$ Carson learned that several cable systems were for sale. ${ }^{120}$ These opportunities were presented at meetings of the members, and they approved further consideration of acquisitions. ${ }^{121}$ An original deal for a package of three of the cable systems fell through, after which Carson came to terms with one of the cable systems through Carson Communications, another company he controlled. ${ }^{122}$ Carson then passed this opportunity along to the LLC with additional terms including an increase in his salary and the calculated value of his equity. ${ }^{123}$ When the LLC failed to move on the new proposal, Carson later closed on the acquisitions through Carson Communications. ${ }^{124}$

Lynch sued Carson and Carson Communications, alleging that Carson breached his fiduciary duties to the LLC by: (a) not presenting the final opportunity to the LLC without additional added terms, and (b) taking the opportunity without approval during a formal meeting of the LLC members. ${ }^{125}$ The operating agreement contained a provision requiring the members to first offer the opportunity to buy cable systems in a delineated geographic area to the LLC and a provision allowing members to engage in competing businesses. ${ }^{126}$ The

116 See Ga. Code AnN. § 14-11-305(A)(4) (West 2003) ("[N]o such provision shall eliminate or limit the liability of a member or manager: (i) For intentional misconduct or a knowing violation of law ....").

117 See Lynch Multimedia Corp. v. Carson Communications, L.L.C., 102 F. Supp. 2d 1261, 1265 (D. Kan. 2000).

118 Id. at 1262.

119 Id.

120 Id. at 1263.

121 Id.

122 Id.

123 Id.

124 Id.

125 Id. at 1264.

126 Id. at 1262-63 ("The two provisions of the Operating Agreement which are central to this case are set forth below: 'Other Cable Systems. Any opportunity which comes to the at- 
court interpreted the two provisions in light of each other, properly holding that they allowed members of the LLC to purchase a cable system in the specified geographic region so long as they first offered the opportunity to the LLC. ${ }^{127}$ Finding no requirement that the opportunity be offered at a formal meeting and noting the passage of time between the original notice of the opportunity and Carson purchasing the cable system, the court held that he had not breached the operating agreement. ${ }^{128}$ The court equated the contract question with the question of fiduciary duties owed, finding that Carson had not breached any fiduciary duties because he had complied with the requirements of the operating agreement and making no challenge to the reduction of fiduciary duties by the operating agreement. ${ }^{129}$

Lynch provides strong support for the enforceability of waivers under Kansas law. ${ }^{130}$ More recently, the court in the District of Kansas held that the Kansas overriding fairness standard did not trump a provision in the operating agreement reducing fiduciary duties. ${ }^{131}$ However, no Kansas state court has yet enforced a waiver or reduction of fiduciary duties. As decisions by federal courts, Lynch and Rajala will not be binding on Kansas state courts, carrying a danger that a Kansas state court may be reticent in applying the plain meaning of the Kansas statute.

\section{Louisiana Case Law}

The first courts to address the enforceability of waiver under Louisiana law were federal, not state, courts. In In re Provenza, the bankruptcy court stated the applicable LLC articles eliminated the alleged damages through a limitation of liability for breaches of fiduciary duty. ${ }^{132}$ But because the court had already determined that no breach of fiduciary duty had occurred, its statement was dicta. ${ }^{133}$ In Sigma Delta, L.L.C. v. George, the district court rejected a motion to

tention of a Member to purchase cable television systems ... shall first be offered to the Company. ... Other Interests. Any Member or Manager may engage independently or with others in other business ventures of every nature and description. Neither the Company nor any Member shall have any right by virtue of this Agreement of the relationship created hereby in or to any other ventures or activities in which any Member or Manager is involved or to the income or proceeds derived therefrom. The pursuit of other ventures and activities by Members or Managers is hereby consented to by the Members and shall not be deemed wrongful or improper." ").

127 Id. at 1264.

${ }^{128}$ Id. at $1264-65$.

129 Id. at 1265 ("Under Kansas law, the members of a limited liability company may expand or restrict their duties and liabilities by the terms of their agreement." (citing KAN. STAT. ANN. § 17-76, 134(c))).

130 See also Rajala v. Gardner, No. 09-2482-EFM, 2012 WL 1189773, at*17 (D. Kan. Apr. 9 , 2012) (holding that Kansas overriding fairness standard did not trump a provision in the operating agreement reducing fiduciary duties).

${ }_{131}^{1}$ Id.

132 In re Provenza, 316 B.R. 225, 232 (Bankr. E.D. La. 2003).

133 Id. 
dismiss, ruling that the indemnification provision in question covered the plaintiffs. ${ }^{134}$ The court did not explicitly address its enforceability and did not indicate if the issue had been raised by Sigma Delta.

It would not be until 2014 that a Louisiana court would speak clearly on the issue. In Broussard v. Tipton, disputes over a failed venture to produce, market, and sell seasoning products led to a claim by Mr. Broussard and an affiliated LLC against Mr. Tipton and two affiliated LLCs for breach of their fiduciary duty of trust and loyalty. ${ }^{135}$ The defendants' motion for summary judgment included an argument that they could not be held liable based on an explicit indemnification provision in the articles of incorporation. ${ }^{136}$ The court upheld the trial court's grant of summary judgment, finding no need to reach the issue of whether the underlying conduct constituted a breach of any fiduciary duty because "the provision for indemnity in the articles of organization clearly eliminates any liability [the defendants] would have."137

But the Broussard court, however definitive its language, issued an unpublished decision. And just three days earlier, the Louisiana Court of Appeal for the Second Circuit in a published decision interpreted a limitation of the duty of loyalty very narrowly. ${ }^{138}$ Accordingly, the law in Louisiana should be regarded as unsettled.

\section{Massachusetts Case Law}

The highest court of Massachusetts recently addressed the enforceability of a waiver of fiduciary duties in Pointer $v$. Castellani. ${ }^{139}$ Pointer, the president and a member of Fletcher Granite Company, LLC, brought various claims against other members of the LLC after a freeze-out. ${ }^{140}$ The defendants counterclaimed for breach of fiduciary duty, arguing that Pointer had been offered an opportunity to participate in the development of several tracts of land and had failed to present the opportunity to the LLC. ${ }^{141}$ The court found that language in the operating agreement "explicitly allowing any member the right "to conduct any other business or activity whatsoever" "absolved Pointer of any duty to pass along a business opportunity "not involved within [the LLC's] line

134 Sigma Delta, L.L.C. v. George, No. 07-5427, 2008 WL 1744798, at *1 (E.D. La. Apr. 11, 2008).

135 Broussard v. Tipton, No. 2013 CA 1268, 2014 WL 3559371, at*1-2 (La. Ct. App. Apr. 24, 2014).

136 Id. at $* 4$

137 Id. (footnote omitted).

138 Monroe Surgical Hosp., L.L.C. v. St. Francis Med. Ctr., Inc., 147 So.3d 1234, 1248-49 (La. Ct. App. 2014).

139 Pointer v. Castellani, 918 N.E.2d 805, 819-21 (Mass. 2009).

$140 \mathrm{Id}$. at 808 .

141 Id. at 819. 
of business." ${ }^{142}$ The court made clear that the operating agreement, not the traditional doctrine of business opportunity, governed. ${ }^{143}$

Pointer disrupted a long series of cases, led by Wartski v. Bedford, ${ }^{144}$ refusing to enforce waivers of fiduciary duty in LP and partnership agreements. Wartski is long settled law in Massachusetts, and courts may be loath to abandon it, more recent precedent to the contrary notwithstanding. Pointer is also the only case enforcing a waiver; however, it is a case decided by the highest court in Massachusetts and will be binding on all lower Massachusetts state courts. A lower court judge wishing to avoid enforcing a waiver of fiduciary duty in the LLC context will be forced to distinguish Pointer.

\section{Missouri Case Law}

Missouri courts only recently addressed the enforceability of a waiver in Hibbs v. Berger. ${ }^{145}$ After ruling that managers of an LLC have fiduciary duties to the members of the LLC under Missouri law, the court noted that LLCs, unlike partnerships or corporations, were permitted to "effectively limit or define the scope of the fiduciary duties imposed upon an LLC's members and manager." 146 Looking then to the LLC's operating agreement, the court found provisions stating that "[a] member who makes a loan to the [LLC] shall have no fiduciary duty ... to not declare a default ... or to not initiate any collection or enforcement actions or proceedings by it as lender," and that members would not be liable for acts made "in good faith and in a manner reasonably believed ... to be within the scope of authority granted ... and in the best interests of the [LLC]." ${ }^{147}$ Thus, the court correctly held that the manager could not be liable for foreclosing on the LLC's assets and that he could not be liable for any other alleged acts because the plaintiff had not proffered anything demonstrating he acted in bad faith. ${ }^{148}$ It is only one case, but it is a strong statement in favor of allowing at least partial waiver that is made more effective by the force and clarity of its reasoning.

\section{North Carolina Case Law}

North Carolina courts have not always been fully appreciative of the strongly contractual nature of LLCs, ${ }^{149}$ but nonetheless the case law has devel-

142 Id.

143 Id. at 820 .

144 Wartski v. Bedford, 926 F.2d 11 (1st Cir. 1991) (holding that a waiver of the duty of loyalty was ineffective in defeating the business opportunity doctrine).

145 Hibbs v. Berger, 430 S.W.3d 296 (Mo. Ct. App. 2014).

146 Id. at 316.

147 Id.

148 Id. at 316-17.

149 See Crouse v. Mineo, 658 S.E.2d 33, 36 (N.C. Ct. App. 2008) (“A limited liability company (LLC) is a 'statutory form of business organization ... that combines characteristics of business corporations and partnerships." (quoting Hamby v. Profile Prods., L.L.C., 652 
oped in a manner favorable toward waivers by LLC members of their fiduciary duties. The question of enforceability of a waiver of the fiduciary duties of an LLC member was first raised in North Carolina in RSN Properties, Inc. v. Jones. ${ }^{150}$ A corporation, RSN Properties, and an individual, Jones, were the sole members of an LLC organized to buy and sell real estate. ${ }^{151}$ The operating agreement allowed the members of the LLC to participate in other business activities, even if those activities were in competition with the LLC. ${ }^{152}$ Through another company, Jones sold two mobile homes purchased at a steep discount to the LLC for the full invoice price. ${ }^{153}$

RSN Properties sued Jones for breach of fiduciary duty for, among other things, converting to himself the profit on the sale of the mobile homes to the LLC. ${ }^{154}$ Although the court noted that the statute allowed an operating agreement to alter the duty of the manager to account, the court did not reach the issue of whether the operating agreement in fact did so. ${ }^{155}$ While the court assumed an interpretation that the operating agreement only allowed participation in competing business would be valid, it left the decision for remand. ${ }^{156}$ The parties apparently settled, and the question of fiduciary waivers in the LLC context in North Carolina remained unresolved by the courts.

The ultimate disposition of RSN Properties left a bankruptcy court with no precedent to apply in In re Allentown Ambassadors, Inc. ${ }^{157}$ The debtor in Allentown was a minor league baseball team (the Allentown Ambassadors) that played in an independent league organized as a North Carolina LLC. ${ }^{158}$ The Ambassadors fell on difficult financial times and filed for chapter 11 bankruptcy in 2004. ${ }^{159}$ The Ambassadors filed a claim in bankruptcy court against the commissioner of the league (a managing member of the LLC and the owner of one of the teams) for breach of fiduciary duty, alleging disparate treatment. ${ }^{160}$ The commissioner had refused to help the Ambassadors find a buyer for the

S.E.2d 231, 235 (N.C. 2007) (quoting RusSELl M RoBINSON, II, RoBINSON ON NoRTH Carolina Corporate Law $\S 34.01$, at 34-2 (rev. 7th ed. 2006)))). But see id. ("The [LLC] Act contains numerous 'default' provisions or rules that will govern an LLC only in the absence of an explicitly different arrangement in the LLC's articles of organization or written operating agreement. Because these default provisions can be changed in virtually any way the parties wish, an LLC is primarily a creature of contract." (quoting RoBINSON, supra, at 34-2 to 34-3)).

150 RSN Properties, Inc. v. Jones, No. COA04-100, 2005 WL 465551, at *2 (N.C. Ct. App.

Mar. 1, 2005).

151 Id. at $* 1$

${ }^{152} \mathrm{Id}$.

153 Id. at *1-2.

154 Id.

$155 I d$. at $* 4$.

156 Id.

157 In re Allentown Ambassadors, Inc., 361 B.R. 422 (Bankr. E.D. Pa. 2007).

$158 I d$. at 426 .

159 Id. at 430.

$160 \mathrm{Id}$. at 460 . 
team and had refused to allow them to "go dark" (i.e., not play for a season and only pay annual dues to the league), despite making similar concessions for other teams during roughly the same time period. ${ }^{161}$ While the bankruptcy court noted that there was no precedent on-point and that the North Carolina LLC Act did not set fiduciary duties, the court nonetheless predicted that a North Carolina state court would hold that the commissioner owed a fiduciary duty to individual members of the LLC. ${ }^{162}$ The bankruptcy court was wrong to analogize to North Carolina corporate law ${ }^{163}$ rather than focusing on the operating agreement and the text of the North Carolina LLC Act. In doing so, the bankruptcy court rejected the argument by the commissioner that the operating agreement served to waive or indemnify his fiduciary duties to the members of the LLC. ${ }^{164}$ The bankruptcy court was likely influenced by what appeared to be unfair treatment by the commissioner, but, because the operating agreement placed no such restrictions on the commissioner, the LLC members had implicitly placed this decision-making at the discretion of the commissioner. The court should not have applied heightened standards based on the exercise of that discretion in treating individual situations differently.

The issue was next raised to a federal district court in Morris v. Hennon \& Brown Properties, L.L.C. ${ }^{165}$ H\&B Properties, a member of three LLCs organized to fund and manage separate construction projects, alleged that Morris, as co-manager of each of the LLCs, had breached his fiduciary duties. ${ }^{166}$ The court noted that, while the operating agreement of an LLC may eliminate the personal liability of a manager for breach of most fiduciary duties, ${ }^{167}$ the operating agreements in question contained no such waiver. ${ }^{168}$ Because it found no waiver and ultimately found $\mathrm{H} \& \mathrm{~B}$ Properties did not have standing to bring a direct action against Morris for breach of fiduciary duties, the court refused to extend its analysis further and clarify the murky state of North Carolina LLC law at the time. ${ }^{169}$ As a federal court interpreting state law, the district court

161 Id. at $429-30$

162 Id. at 461 (citing Farndale Co. v. Gibellini, 628 S.E.2d 15, 19 (N.C. Ct. App. 2006); Freese v. Smith, 428 S.E.2d 841, 848 (N.C. Ct. App. 1993); Loy v. Lorm Corp., 278 S.E.2d 897, 901 (N.C. Ct. App. 1981)).

163 Id.

164 Id. at 460-61 ("Section 3.5 of the Operating Agreement provides: 'No Member of the Company shall be liable to the Company for monetary damages for an act or omission in such Member's capacity as a Manager, except as provided in the Act for (I) acts or omissions which a Member knew at the time of the acts or omissions were clearly in conflict with the interests of the Company; (ii) any transaction from which a Member derived an impersonal benefit." ").

165 Morris v. Hennon \& Brown Props., L.L.C., No. 1:07CV780, 2008 WL 2704292 (M.D.N.C. July 3, 2008).

166 Id. at $* 1$.

167 See N.C. Gen. StAT. AnN. § 57C-3-31 (West 2011) (repealed 2014).

168 Morris, 2008 WL 2704292, at *2.

$169 I d$. at *4-6. The court did, however, cite to the leading treatise on business association law in North Carolina: "The duties of good faith, due care, and loyalty may not be eliminated 
was correct in refusing to provide guidance even in dicta. ${ }^{170}$ Thankfully, the enforceability of a waiver of fiduciary duty under North Carolina law was only to remain unresolved for another year.

Authoritative, albeit incomplete, guidance was finally given by a North Carolina state appellate court in Kaplan v. O.K. Technologies, L.L.C. ${ }^{171}$ The plaintiff, Kaplan, and an existing company, AEI, organized O.K. Technologies, L.L.C., to develop, manufacture, and sell aquarium components, assigning all of AEI's intellectual property to the LLC. ${ }^{172}$ Kaplan owned the largest stake in the LLC, but the operating agreement specified that management decisions required the approval of a "Majority in Interest." 173 Kaplan made extensive loans to the LLC. ${ }^{174}$ Less than three years after organizing the LLC, the members voted to dissolve it. ${ }^{175}$

When the LLC failed to repay Kaplan's loans within a couple of months, he filed suit. ${ }^{176}$ O.K. Technologies' counterclaim for breach of fiduciary duty was at issue in the appeal. ${ }^{177}$ The court implicitly rejected O.K. Technologies' characterization of the closely held LLC as a partnership. ${ }^{178}$ Relying on the North Carolina LLC Act, ${ }^{179}$ the court upheld a provision in the operating agreement limiting liability of a member of the LLC to any other member to three explicit exceptions (none of which were implicated by the facts of the case). ${ }^{180}$

Interestingly, despite the plain reading of both the applicable provision of the statute and the applicable provision of the operating agreement as providing for exculpation from liability, the court in Kaplan characterized the waiver as limiting the duties of the managers of the LLC. ${ }^{181}$ A true waiver of fiduciary

or restricted by agreement of the members [of the LLC] . ..." Id. (quoting RoBINSON, supra note $149, \S 34.04[3]$, at 34-23 to 34-24.1).

170 This highlights one of the inherent roadblocks to the development of LLC case law. Because many LLCs are formed by sophisticated parties and involve large sums of money (particularly those that involve waivers of fiduciary duty), the parties frequently take advantage of choice of law principles to agree contractually to settle disputes in federal district court. They are also more likely to have complete diversity. Those courts can provide neither precedent binding to the state courts nor will they provide guidance via dicta.

171 Kaplan v. O.K. Techs., L.L.C., 675 S.E.2d 133 (N.C. Ct. App. 2009).

172 Id. at 135 .

173 Id.

174 Id.

175 Id. at 136.

176 Id.

177 Id.

$178 I d$. at 140 ("[Defendants] also argue that Kaplan owed them a fiduciary duty based on the sole fact that O.K. was a closely-held LLC. [Defendants] argue that the relationship between members of a closely-held LLC is like the fiduciary relationship between partners in a partnership. [Defendants], however, ignore the fact that by their operating agreement, the parties expressly limited the duties the member-managers owed." (citations omitted)).

179 See N.C. Gen. StAT. ANN. § 57C-3-32(a) (West 2011) (repealed 2014).

180 Kaplan, 675 S.E.2d at 140.

181 Id. 
duty might be better supported by the general contractual nature of the LLC and the lack of language in the North Carolina LLC Act expressly disallowing waiver, rather than an exculpation provision expressly mentioning only monetary damages. ${ }^{182}$ However confused the statutory interpretation is, Kaplan provides a strong precedent for the enforcement of a waiver of fiduciary duty under North Carolina law.

\section{Nevada Case Law}

The waiver question has not been addressed under Nevada law since the Nevada legislature liberalized its LLC Act to directly allow even the elimination of fiduciary duties by contract in the operating agreement. ${ }^{183}$ The Nevada federal district court, however, has dealt with the issue between the passage and effective date of the amendments to the Nevada LLC Act. The defendants in JPMorgan Chase Bank, N.A. v. KB Home, several real estate companies, had organized a Nevada LLC in order to develop a large tract of land in Henderson, Nevada. ${ }^{184}$ JPMorgan led the syndicate financing of the initial purchase. ${ }^{185}$ The original plan called for the members of the LLC to purchase parcels of the full tract from the LLC; however, the members subsequently refused to do so, forcing construction to stop and the LLC to default on its loan agreement with JPMorgan. ${ }^{186}$

JPMorgan sued the members and their parent companies for, among other things, breaches of fiduciary duties. ${ }^{187}$ JPMorgan responded to the waiver provision in the operating agreement by asserting that it was invalid under Nevada law. ${ }^{188}$ Analogizing LLCs to partnerships, JPMorgan relied on the Nevada Partnership Act ${ }^{189}$ to argue that waivers of fiduciary duty should be restricted for LLC members in a manner similar to that for partners. ${ }^{190}$ The court noted that the Nevada LLC Act contained no such restriction and that the Nevada Supreme Court had not addressed "whether such a restriction nonetheless should be implied." 191 Again, a federal district court was faced with the uncomfortable task of predicting how a state court would address the enforceability of a waiv-

182 See N.C. Gen. Stat. ANN. § 57C-3-32(a) (West 2011) (repealed 2014) (“Subject to subsection (b) of this section, . . . a written operating agreement may: (1) Eliminate or limit the personal liability of a manager, director, or executive for monetary damages for breach of any [fiduciary] duty provided for in [section] 57C-3-22 ...”). Chapter 57C was repealed in 2014 , but its replacement, chapter 57D, is hardly a model of clarity, only indirectly allowing for waiver.

183 NEV. ReV. Stat. § 86.286(7) (2013) (relevant section added in 2009).

184 JPMorgan Chase Bank, N.A. v. KB Home, 632 F. Supp. 2d 1013, 1018 (D. Nev. 2009).

185 Id.

186 Id. at $1018-19$.

187 Id. at 1019.

188 Id. at 1024.

189 Nev. Rev. StAT. § 87.4316(2) (2013).

190 KB Home, 632 F. Supp. $2 \mathrm{~d}$ at 1024.

191 Id. 
er of fiduciary duties without any clear statutory or case law guidance. The court properly assumed that, had the Nevada Legislature intended for the same restrictions imposed on partnerships to apply to LLCs, the Nevada Legislature would have included provisions in the LLC Act similar to those in the partnership act. ${ }^{192}$ The court also interpreted the recently passed changes to the Nevada LLC Act directly allowing elimination of fiduciary duties as reiterating that intent, ${ }^{193}$ in what was perhaps a backdoor application of a law that had not yet taken effect.

Given that no case addressing the enforceability of a waiver under Nevada law has been decided since the Nevada LLC Act was liberalized to imitate the Delaware LLC Act, JP Morgan can be considered the leading case on the question. However, it is a federal district court case and will not be binding on Nevada state courts. The only other case addressing the question of a waiver of fiduciary duties under the Nevada LLC Act-Kira, Inc. v. All Star Maintenance ${ }^{194}$ — was decided by a federal district court in Texas and was decided prior to the changes to the Nevada LLC Act.

\section{Texas Case Law}

Texas courts have addressed - albeit tangentially - the enforceability of a waiver of fiduciary duties in a single case. The court in Allen v. Devon Energy Holdings, L.L.C., noted that the Texas Business Organizations Code left the LLC's members "free to expand or eliminate, as between themselves, any and all potential liability of [the LLC's manager], as they saw fit," but ultimately held that that the manager's actions violated his fiduciary duty as defined in the operating agreement. ${ }^{195}$ Thus, no court in Texas has actually enforced a waiver of fiduciary duty by LLC members.

\section{Case Law Departing from the Approach of Delaware Courts}

Not every state's courts have been as open to waiver of fiduciary duties by LLC members as have those in Delaware. However, only two of the states classed with Delaware have been truly hostile-New York and California.

192 Id. at 1025.

193 Id. at $1025-26$.

194 Kira, Inc. v. All Star Maint., No. A-03-CA-950 LY, 2006 WL 2193006, at*15 (W.D. Tex. July 31,2006 ) (interpreting a waiver of the duty of loyalty very narrowly and thus finding a breach of fiduciary duty).

195 Allen v. Devon Energy Holdings, L.L.C., 367 S.W.3d 355, 396 (Tex. App. 2012). The judgment was ultimately set aside and remanded by agreement of the parties, but the court refused to withdraw its original opinion. See Allen v. Devon Energy Holdings, L.L.C., No. 01-09-00643-CV, 2013 WL 273026, at*1 (Tex. App. 2013). 


\section{New York Case Law}

In 2002, a New York court addressed a release of all claims in the LLC context in TIC Holdings, L.L.C. v. HR Software Acquisition Group, Inc. ${ }^{196}$ The court interpreted the release narrowly, reasoning that if it construed it according to its own terms, it "would be insupportably broad." 197 That construction was not founded on a mere reluctance to give the parties the benefit of the bargain, but a recognition that such a "construction would render much of the language contained in the ... release mere surplusage." 198 The court did further state, however, that a full release would be ineffective because a release cannot under New York law "insulate a releasee from wilful or intentional misconduct."199 The Appellate Division did not reach the issue, holding that it was "unclear whether [the defendants'] conduct falls within either of the provisions relied upon." ${ }^{200}$ The Supreme Court of New York, New York County, again very narrowly construed a provision limiting liability, this time an exculpatory clause, in Arfa v. Zamir. ${ }^{201}$

It would not be until 2012 that New York's highest court would address the issue in Pappas v. Tzolis. ${ }^{202}$ Plaintiffs Pappas and Ifantopoulos and defendant Tzolis formed a LLC to lease a building in lower Manhattan long-term, with Pappas and Ifantopoulos contributing $\$ 50,000$ and $\$ 25,000$, respectively. ${ }^{203}$ The original LLC agreement provided that the three members of the LLC could "engage in business ventures and investments of any nature whatsoever, whether or not in competition with the LLC." 204 After numerous business disputes, and one year after the LLC was formed, Tzolis bought out Pappas's and Ifantopoulos's membership interests in the LLC for $\$ 1,000,000$ and $\$ 500,000 .{ }^{205}$ The Agreement of Assignment and Assumption included a provision that "Tzolis has no fiduciary duty to the undersigned Sellers in connection with [the] assignments. ${ }^{" 206}$ Seven months later Tzolis assigned the lease to a third-party for $\$ 17,500,000 .{ }^{207}$ Pappas and Ifantopoulos sued, alleging that Tzolis had already been in surreptitious negotiations to assign the lease when

196 TIC Holdings, L.L.C. v. HR Software Acquisition Grp., Inc., 750 N.Y.S.2d 425 (Sup. Ct. 2002).

197 Id. at 112.

198 Id. at $112-13$.

199 Id. at 113.

200 TIC Holdings, L.L.C. v. HR Software Acquisitions Grp., Inc., 755 N.Y.S.2d 19, 20 (App. Div. 2003).

201 See Arfa v. Zamir, 873 N.Y.S.2d 231 (Sup. Ct. 2008) (interpreting a clause expressly limiting liability for acts in good faith as not modifying the duty of loyalty).

202982 N.E.2d 576 (N.Y. 2012).

203 Id. at 578 .

${ }^{204} \mathrm{Id}$.

205 Id.

$206 I d$. (alternation in original).

207 Id. 
he bought them out, and he breached his fiduciary duties to them by failing to disclose the negotiations. ${ }^{208}$

The court ultimately upheld the release from claims based on fiduciary duty, but in doing so it did not rely on, look to, or interpret the relevant New York statute. Instead, the court relied on a case interpreting the duties and law applicable to the majority shareholder in a closely held corporation. ${ }^{209}$ The New York statute provides that the operating agreement may eliminate or limit damages for breach of a duty, except for acts or omissions that are in bad faith, involve intentional misconduct or a knowing violation of law, or that result in a financial profit or other advantage that the member was not entitled to. ${ }^{210} \mathrm{In}$ stead, the court relied on a broader principle of New York law that waivers of fiduciary duty are enforceable where the releasing party is sophisticated and "the fiduciary relationship is no longer one of unquestioning trust." 211 The court held that Pappas and Ifantopoulos were sophisticated parties and that the relationship of trust had been destroyed by the disputes among the members. ${ }^{212}$ The court reached the correct result-enforcing the release; but reached it on the wrong basis - failing to apply the plain language of the statute. ${ }^{213}$

\section{California Case Law}

A California court first addressed the enforceability of a waiver of fiduciary duties between LLC members in USAT Reorganization L.L.C. v. Writer. ${ }^{214}$ Krintzman, an attorney, and Writer, one of his clients, formed a two-member LLC for the sole purpose of purchasing a corporation (stock in the corporation was to be the LLC's only asset). ${ }^{215}$ After disputes arose between the two, they negotiated an operating agreement that set the members' rights and obligations. ${ }^{216}$ By agreement, ${ }^{217}$ the two agreed to release the other from any claims

208 Id.

${ }^{209}$ Id. at 579 (relying on Centro Empresarial Cempresa S.A. v. America Movil, S.A.B. de C.V., 952 N.E.2d 995 (N.Y. 2011)).

210 N.Y. LTD. Liab. Co. LAW § 417(a) (McKinney 2016).

211 Pappas, 982 N.E.2d at 579 (quoting Centro Empresarial, 952 N.E.2d at 1001).

212 Id.

213 See also Sybron Can. Holdings, Inc. v. Niznick, No. 650908/14, 2015 N.Y. Misc. LEXIS 352, at *35-36 (N.Y. Sup. Ct. Feb. 3, 2015) (ruling the contract was ambiguous); DeBenedictis v. Malta, No. 602537/2008, 2014 N.Y. Misc. LEXIS 5862, at *5-9 (N.Y. Sup. Ct. Mar. 6, 2014) (ruling that fiduciary duties cannot be modified or eliminated absent explicit language to that effect); Kafa Invs., L.L.C. v. 2170-2178 Broadway, L.L.C., 958 N.Y.S.2d 577, 580-84 (Sup. Ct. 2013) (enforcing a broad release where the plaintiffs were sophisticated parties).

214 USAT Reorganization L.L.C. v. Writer, No. D043230, 2004 WL 2538848 (Cal. Ct. App. Nov. 10, 2004).

215 Id. at *1-2.

216 Id. at $* 2$.

217 It is not entirely clear from the court's opinion whether this was a part of the operating agreement or a separate agreement signed on the same day. However, the court does not distinguish on this basis and there is no reason to believe that it being part of the operating 
related to the management of the LLC for actions on or before the date of the agreement. ${ }^{218}$ That agreement gave Writer majority control of the LLC and made him its sole manager. ${ }^{219}$ Writer promptly began using his position to shift control of the corporation from the LLC to himself and his confederates. ${ }^{220}$

Krintzman, individually and derivatively through the LLC, filed suit against Writer, et al., alleging, among other things, breach of a number of fiduciary duties. ${ }^{221}$ Despite the language of the release signed earlier by both parties, ${ }^{222}$ the court interpreted the agreement to have no effect on Writer's fiduciary duties to the LLC. ${ }^{223}$ The court noted that the California LLC Act set the fiduciary duties of an LLC manager to the LLC as those of a partner to the partnership ${ }^{224}$ and applied in the LLC context case law holding that fiduciary duties related to fundamental partnership business. ${ }^{225}$

The court in Writer was surely influenced by Writer blatantly taking advantage of the terms of the settlement agreement. However, that was a path that Krintzman chose to leave open in negotiating the settlement, and it is difficult to say that Krintzman was not a sophisticated investor relative to his client, Writer. The court failed to engage in a full analysis of the California LLC Act, instead relying on partnership cases that are likely irrelevant given the text of the California LLC Act. ${ }^{226}$ A court interpreting California law is unlikely to dive into said statutory analysis now that Writer has provided a negative precedent, especially with the LLC Act ostensibly allowing for waiver having been repealed.

\section{No Case Law Available}

In the remaining fourteen states, ${ }^{227}$ no court has directly considered whether a waiver of fiduciary duty is enforceable. This leaves tremendous uncertainty

agreement, if it was in fact not, would have made any difference in the disposition of the case. So, for the purposes of this article, it will be assumed that the provision was part of the operating agreement. See id.

$218 I d$. at $* 16$.

219 Id. at $* 2$.

$220 I d$. at $* 2-3$.

221 Id. at *3-4, *9.

${ }^{222} \mathrm{Id}$. at $* 16$ (quoting the agreement in releasing claims "arising out of or in connection with, or relating in any way to" the management of the LLC "up to and including the date of this agreement" as well as any related fiduciary relationship between Krintzman and Writer or the LLC).

223 Id. at $* 16-17$.

224 See CAL. CORP. CODE app. § 17153 (West 2014) (repealed 2014).

225 Writer, 2004 WL 2538848, at *19 ("The fiduciary obligations of a general partner with respect to matters fundamentally related to the partnership business cannot be waived or contracted away in the partnership agreement." (quoting Everest Investors 8 v. McNeil Partners, 8 Cal. Rptr. 3d 31, 40 (Cal. Ct. App. 2003))).

226 See infra Part III.C (interpreting the California LLC Act).

227 Alabama, Arkansas, Colorado, Connecticut, Kentucky, Maine, Maryland, Massachusetts, Michigan, Mississippi, New Hampshire, New Mexico, Washington, and Wisconsin. It 
for parties considering forming an LLC and desiring to modify or waive fiduciary duties. A planning attorney must look to the statutory text and to LP case law to divine predicted treatment of a waiver of fiduciary duties for LLC members.

Courts in each state will likely be amenable to operating agreement provisions expanding fiduciary duties, because the focus of the law had traditionally been on protecting the party in a vulnerable position in a fiduciary relationship. Likewise, albeit to a lesser extent, courts will be more open to redefinition or modification of fiduciary duties in a way that does not reduce the overall duties of the members. Courts can also be expected to be more likely to enforce highly detailed provisions as opposed to very broad, all-encompassing provisions, which can more easily be interpreted in a narrow fashion to avoid waiving the alleged breach before the court.

\section{E. Final Analysis}

With an unparalleled body of precedent, waivers can be approached with the most certainty for Delaware LLCs. Georgia and North Carolina both offer multiple favorable decisions. Only one precedent exists in Kansas, but it is a positive one uncontroverted by statutory ambiguity or negative LP case law. Massachusetts law also contains a single positive precedent and clear statutory support for waiver, but dangerous negative LP case law exists. The only positive precedent in Louisiana is an unpublished opinion. After revisions to the Nevada LLC Act, planning attorneys can be confident that waivers will be enforced under Nevada law. Case law in Texas should be considered unsettled with only a single case in support, and that language is arguably dicta. A court in California, on the other hand, has provided clear precedent that a waiver of fiduciary duties will not be enforced, even for LLCs formed before the California LLC Act was repealed and replaced with one following the ULLCA approach. New York courts have also made clear they will enforce requirements outside of the statute before enforcing a waiver. Planning attorneys in states without LLC precedent, on the other hand, must make inferences about the enforceability of waivers based on statutory text and LP case law. Taken together, the above shows that the enforceability of a waiver of fiduciary duties in the LLC context is far from a given, even in the states with the most permissive language in their respective LLC statutes.

should be noted, however, that courts in Connecticut will take an equitable approach and look to the operating agreement in defining fiduciary duties for LLC members. See Binder v. Windmill Mgmt., L.L.C., No. FSTX08CV106004435S, 2013 WL 593936, at*11 (Conn. Super. Ct. Jan. 17, 2013) (relying on control provisions of the operating agreement in holding that no member was in a position to dominate the relationship and thus there were no fiduciary duties). 


\section{ANALYSIS OF THE STATUTORY TEXT}

Very little case law deals directly with the enforceability of waivers of fiduciary duties. In a sort of self-fulfilling prophecy, this may be due to planning attorneys advising their clients against including such waivers due to the uncertainty created by a lack of case law. Absent binding authority to rely on, it becomes necessary to look to the statutory text to better understand the expected approach in states lacking adequate authority. This section examines the statutory text in states adopting each of the five sub-approaches under the umbrella Delaware approach. Part A examines the statutory text in states taking the direct approach. Part B analyzes the text for states that provide for waiver only indirectly. Part $\mathrm{C}$ and Part $\mathrm{D}$ examine the text for states that modify a direct approach by failing to provide directly for elimination or by adding caveats, respectively. Part E examines the text of states only providing for exculpation. Part $\mathrm{F}$ provides a final analysis showing that despite being categorized as a Delaware approach, the proper interpretation varies quite a bit from subapproach to sub-approach.

\section{A. Direct Approach}

Delaware, Nevada, Alabama, and New Hampshire make the clearest and strongest statements allowing full waiver of all fiduciary duties. ${ }^{228}$ There remains no restriction on waivers in either state beyond the covenant of good faith and fair dealing implicit in all contracts. ${ }^{229}$ All four states also expressly provide for a policy giving "maximum effect to the principle of freedom of contract and to the enforceability" of the operating agreement. ${ }^{230}$ Delaware additionally provides that the common law rule governing statutory provisions conflicting with the common law is not applicable to the section providing for waivers of fiduciary duties. ${ }^{231}$ While a case has yet to enforce complete elimi-

228 See supra note 55 and accompanying text; see also 1 RiBSTEIN \& KEATINGE, supra note 37.

229 AlA. CODE § 10A-5A-1.08(b)(1) (Supp. 2015) ("To the extent that, at law or in equity, a member or other person has duties, including fiduciary duties, to the limited liability company, or to another member or to another person that is a party to or is otherwise bound by a limited liability company agreement, the member's or other person's duties may be expanded or restricted or eliminated by a written limited liability company agreement, but the implied contractual covenant of good faith and fair dealing may not be eliminated."); DEL. CODE ANN. tit. 6, § 18-1101(e) (2016) ("[A] limited liability company [operating] agreement may not limit or eliminate liability for any act or omission that constitutes a bad faith violation of the implied contractual covenant of good faith and fair dealing."); NEV. REV. STAT. $\S 86.286(7)$ (2013) (tracking the Delaware act's provision almost word-for-word); N.H. REV. STAT. ANN. § 304-C:107 (2015) (using the exact language of the Alabama provision).

230 Ala. Code § 10A-5A-1.06(a) (Supp. 2015); Del. Code AnN. tit. 6, § 18-1101(b) (2016); NEV. REV. STAT. § 86.286(4)(b) (2013) (containing more forceful language than the Delaware provision and stating that the operating agreement "must be interpreted and construed" in such a manner); N.H. Rev. StAT. AnN. § 304-C:2 (2015).

231 See Del. CoDE ANN. tit. 6, § 18-1101(a) (2016) ("The rule that statutes in derogation of the common law are to be strictly construed shall have no application to this chapter."). This 
nation of fiduciary duties, the Delaware, Nevada, Alabama, and New Hampshire statutes provide for it in the strongest and clearest language possible..$^{232}$

\section{B. Indirect Approach}

Arkansas LLC case law is very sparse, and no court has addressed a waiver of fiduciary duties. ${ }^{233}$ The Arkansas LLC statute only indirectly allows waiver of fiduciary duties. The Arkansas LLC Act sets the duty of care to a "gross negligence or willful misconduct" level "[u]nless otherwise provided in an operating agreement." 234 The duty of loyalty is not addressed at all. This stands in stark contrast with the Arkansas LP Act, which explicitly sets fiduciary duties, ${ }^{235}$ and puts express constraints on contractual restrictions on those duties. ${ }^{236}$ The failure of the Arkansas legislature to provide the same level of guidance concerning fiduciary duties for LLCs as for LPs suggests that the legislature intended for members of LLCs to have the ability to more freely contract away fiduciary duties. Courts may still be tempted to simply co-opt LP case law rather than take a critical look at the statutory text, but the enforceability of a waiver for partners in an LP has not been addressed by an Arkansas court (unsurprising, given how clearly the Arkansas LP Act limits waiver).

No case has directly addressed whether fiduciary duties may be waived by LLC members under New Mexico or Wisconsin law. The applicable provisions of both the New Mexico LLC Act and the Wisconsin LLC Act are highly similar to the corresponding provisions in the Arkansas statutes. They both use the same "[u]nless otherwise provided [by or in] . . . an operating agreement" language used by the Arkansas LLC Act. ${ }^{237}$ The New Mexico LLC Act also gives no guidance regarding business opportunity doctrine or competing with the LLC. The best interpretation of the New Mexico statute is the same as for the Arkansas statute - the legislature intended for members of LLCs to have the

should prevent a court in Delaware or Nevada from treating analysis of a waiver as a matter of common law fiduciary duties, but rather as a matter of contract law (albeit one that may lead to traditional fiduciary duty analysis where the parties leverage the common law terms of art in their contract). See Myron T. Steele, Judicial Scrutiny of Fiduciary Duties in Delaware Limited Partnerships and Limited Liability Companies, 32 DEL. J. CoRP. L. 1, 14 (2007) (applying these principles to lay out a framework for an analysis under Delaware law).

232 But see Steele, supra note 231, at 22 ("Delaware courts remain reluctant to leave the secure ground of fiduciary duty common law so well fleshed out in corporate governance decisions even in the face of a statute instructing them to do so.").

233 See Michael A. Thompson, An Uncertain Duty: K.C. Properties, Inc. v. Lowell Investment Partners, LLC and the Duty of Loyalty in an Arkansas Limited Liability Company, 62 ARK. L. REV. 563, 574-75 (2009) (discussing briefly the three cases addressing the substantive rights of LLC members).

234 ARK. CODE ANN. § 4-32-402 (West 2004).

235 See id. $\S 4-47-408$.

236 See id. $\S 4-47-110(\mathrm{~b})(5)$ (stating that the duty of loyalty may not be eliminated); id. $\S 4-$ 47-110(b)(6) (stating that the duty of care may not be reduced unreasonably).

237 N.M. StaT. ANN. § 53-19-16 (West 2003); Wis. STAT. § 183.0402 (West 2014). 
ability to freely contract away fiduciary duties. Interpretation of the Wisconsin LLC Act is a little more complicated. Its provision on the duties of managers and members also provides that "[a]n operating agreement may impose duties on its members and managers that are in addition to those provided [above]." 238 That provision should be interpreted as merely providing clarity that an operating agreement may modify duties up as well as down, but it is an example of exceedingly poor drafting and its interpretation by a court cannot be predicted with confidence.

The Maryland LLC Act takes a different track, providing that "the policy of this title is to give the maximum effect to the principles of freedom of contract and to the enforceability of operating agreements"239_-language used by other states amenable to waiver, including Delaware - but without any more explicit language. The Maine LLC Act turns the direct approach on its head, stating that "[a] limited liability company agreement may not ... [e]liminate or limit a member's liability to the limited liability company and members for monetary damages for a bad faith violation of the implied contractual covenant of good faith and fair dealing." 240

\section{Direct Approach with No Mention of Elimination}

Five states directly provide for waiver of fiduciary duties but omit any mention that fiduciary duties may be "eliminated." 241 At first blush it may seem that because the word "eliminate" is not used, legislatures intended to allow parties to reduce fiduciary duties to some level not rising to a complete waiver. The language of the statutes stands in contrast to that of the Delaware, Nevada, Alabama, and New Hampshire statutes, which do use the word eliminate.

However, the omission of "eliminate" alone does not prevent, or even lead inexorably to, a construction of the statute allowing complete waiver. That is, there is nothing in the text overtly preventing elimination. Perhaps more importantly, any reliance on the presence of the word "eliminate" in the text of the Delaware statute would be misplaced. The Delaware statute, on which these statutes were likely modeled, did not contain the word "eliminate" until the legislature added it in 2004. The Delaware legislature was acting in response to dicta in the Delaware Supreme Court decision for Gotham Partners, L.P. v. Hallwood Realty Partners, L.P.,${ }^{242}$ expressing the opinion of the court that the current language did not allow for the elimination of fiduciary duties. ${ }^{243}$ It appears that the intent of the legislature all along was to allow fiduciary duties to

238 Wis. STAT. $\S 183.0402(3)$.

239 Md. COdE ANn., CoRPs. \& AsS'NS § 4A-102 (LexisNexis 2016).

240 ME. STAт. tit. 31, § 1522(1)(F) (2011).

241 See supra note 57 (California, Kansas, Massachusetts, Missouri, and Texas).

${ }^{242}$ Gotham Partners, L.P. v. Hallwood Realty Partners, L.P., 817 A.2d 160, 167-68 (Del. 2002).

${ }^{243}$ See Steele, supra note 231, at 10-14, 17 (discussing the evolution of the Delaware LP Act). 
be completely eliminated; it only became necessary to clarify their intent due to confusion created by the Delaware Supreme Court. Kansas courts, in particular, are likely to favor an interpretation that squares with Delaware law. ${ }^{244}$

Statutory waiver provisions often must be interpreted in conjunction with multiple provisions, which may be difficult to reconcile. California's former provision is particularly troublesome. An analysis starts out innocuously enough, with section 17005 directly stating that "[t]he fiduciary duties of a manager to the limited liability company and to the members of the limited liability company may only be modified in a written operating agreement with the informed consent of the members." ${ }^{45}$ Unfortunately, other provisions of the California Corporate Code complicate matters. Section 17153 provides that " $[t]$ he fiduciary duties a manager owes to the limited liability company and to its members are those of a partner to a partnership and to the partners of the partnership." ${ }^{246}$ Turning to the partnership section of the Code, we find that the duties of loyalty and care are defined in section $16404 .^{247}$ Section 16103 provides that a partnership agreement may not eliminate the duty of loyalty or unreasonably reduce the duty of care, but allows carve-outs from the duty of loyalty for "specific types or categories of activities." 248

These four provisions do not leave the proper application of California law entirely clear. The most reasonable interpretation is that only section 16404 and not section 16103 should be incorporated into LLC doctrine by section 17153, thus making section 17005 the controlling provision regarding waivers. The language of section 17153 only sets the fiduciary duties of LLC managers to that of partners in a partnership; it does not speak to waiver or modification of those duties. ${ }^{249}$ The only provision in the California LLC Act that does is section 17005 , thus it should govern..$^{250}$

California courts have been quick to rely on partnership case law in stating that partners cannot contract out of their fiduciary duties, ${ }^{251}$ but an interpretation of the four applicable provisions that is not manifestly unreasonable can

244 See Edwin W. Hecker, Jr., Fiduciary Duties in Business Entities, 54 U. KAN. L. REV. 975 , 975 (2006) (observing that courts in Kansas have noticed the legislature's acceptance of Delaware's leadership in applying Delaware case law as persuasive authority). The Kansas LLC Act has now been amended to directly provide for elimination. See KAn. STAT. AnN. $\S 17-76,134$ (c) (West 2014).

245 CAL. CORP. CODE app. $§ 17005(\mathrm{~d})$ (West 2014) (repealed 2014).

${ }^{246}$ Id. app. $\S 17153$ (repealed 2014).

247 Id. $\$ 16404$.

248 Id. $\S 16103(\mathrm{~b})(3)-(4)$.

249 See id. app. $\$ 17153$ (repealed 2014).

250 See id. app. $\$ 17005$ (d) (repealed 2014).

251 See, e.g., Woodson v. Legacy Partners 2323 L.P., No. A100627, 2003 WL 22795886, at *4 (Cal. Ct. App. Nov. 25, 2003) (holding that refinancing the debt of the development owned by the LP was fundamentally related to the partnership business and thus could not be covered by a waiver of fiduciary duties); BT-I v. Equitable Life Assurance Soc'y of the U.S., 89 Cal. Rptr. 2d 811, 816 (Ct. App. 1999) (holding that fiduciary duties fundamental to the relationship between the parties cannot be waived). 
support the same. If section 17153 is interpreted as incorporating both sections 16404 and 16103 into LLC doctrine, then section 17005 must be reconciled with section 16103. Section 17005 states that fiduciary duties "may only be modified in a written operating agreement." ${ }^{" 252}$ The most reasonable interpretation of this language in light of the exact delineations around permissible modifications in section 16103 is that it merely adds an additional requirement that a modification of fiduciary duty must be included in the operating agreement. The court in USAT did not perform this analysis. Instead, it noted that the LLC Act set fiduciary duties for members to those of a partner and jumped directly to an analysis of partnership case law. ${ }^{253}$ Now that there is precedent on which a court can rely, it is doubtful that said court would perform a full statutory analysis, particularly when that analysis may not support the existing precedent and when the relevant statutory provisions have been repealed.

\section{Direct Approach with Caveats}

The Georgia, Washington, Colorado, and Mississippi LLC acts provide directly for waiver but include caveats. The Georgia and Washington LLC acts both provide that fiduciary duties may be waived - even going so far as to use the "elimination" language avoided by so many states - but add caveats, or "carve-outs," from what may be eliminated. ${ }^{254}$ The Georgia LLC Act provision applicable to waiver of the duty of care is admirably clear, opting to restrict waiver only for "intentional misconduct or a knowing violation of law." ${ }^{255}$ The provision addressing the duty of loyalty, on the other hand, on its face only restricts eliminating liability for a transaction breaching the operating agreement. ${ }^{256}$ The language appears circular, but the most reasonable reading is that

252 CAL. CORP. CODE app. $§ 17005$ (d) (West 2014) (repealed 2014) (emphasis added).

253 See USAT Reorganization L.L.C. v. Writer, No. D043230, 2004 WL 2538848, at *19 (Cal. Ct. App. Nov. 10, 2004) ("The fiduciary obligations of a general partner with respect to matters fundamentally related to the partnership business cannot be waived or contracted away in the partnership agreement." (quoting Everest Investors 8 v. McNeil Partners, 8 Cal. Rptr. 3d 31, 40 (Cal. Ct. App. 2003))).

${ }^{254}$ See supra note 58 and accompanying text; see also RiBSTEIN \& KEATINGE, supra note 37. 255 GA. CODE ANN. § 14-11-305(4)(A)(i) (West 2003) ("To the extent that . . . a member or manager has duties (including fiduciary duties) and liabilities relating thereto to a limited liability company or to another member or manager: (A) The member's or manager's duties and liabilities may be expanded, restricted, or eliminated by provisions in . . . a written operating agreement; provided, however, that no such provision shall eliminate or limit the liability of a member or manager: (i) For intentional misconduct or a knowing violation of law ....").

${ }^{256}$ Id. $\S 14-11-305(4)(\mathrm{A})(\mathrm{ii})$ ("To the extent that . . . a member or manager has duties (including fiduciary duties) and liabilities relating thereto to a limited liability company or to another member or manager: (A) The member's or manager's duties and liabilities may be expanded, restricted, or eliminated by provisions in . . . a written operating agreement; provided, however, that no such provision shall eliminate or limit the liability of a member or manager: . . . (ii) For any transaction for which the person received a personal benefit in violation or breach of any provision of a written operating agreement ....”). 
it prevents a waiver of the duty of loyalty from negating any other provision in the operating agreement. While Georgia courts have enforced waivers, they have not yet addressed the proper interpretation of this provision. ${ }^{257}$ The Washington LLC Act also limits restrictions on waiver to "intentional misconduct or a knowing violation of the law," 258 but does not restrict that limitation to the duty of loyalty. The Mississippi LLC Act uses different language but to the same end, prohibiting limiting liability for " $[\mathrm{a}] \mathrm{n}$ intentional infliction of harm on the limited liability company or its members," "[a]n intentional violation of criminal law," and "a bad faith violation of the implied contractual covenant of good faith and fair dealing." 259

The language of the Colorado LLC Act, on the other hand, introduces quite a bit of uncertainty. ${ }^{260}$ But for two words, the Colorado provision for waiver would allow for a level of contractual freedom that would rival Delaware and Nevada. That caveat, however, that anything is permitted "as long as any such provision is not manifestly unreasonable," makes all the difference. ${ }^{261}$ The term "manifestly unreasonable" appears to be borrowed directly from the ULLCA, ${ }^{262}$ and as such it would be appropriate for courts to look to case law in states that have adopted the ULLCA. There are pitfalls to this approach, however. The "manifestly unreasonable" language in the ULLCA refers only to waivers of the duty of loyalty; a court should not apply the stricter "unreasonable" standard the ULLCA applies to waivers of the duty of care. ${ }^{263}$ A court should also not limit a waiver of the duty of loyalty to the categories identified by the ULLCA. ${ }^{264}$ The greatest danger, however, is that the amorphous "manifestly unreasonable" standard gives courts an avenue to an ex post veto over an ex ante, contractual business decision and seriously erodes the certainty on which businesses thrive.

257 See supra Section II.B.1.

258 WASH. Rev. CODE $\S 25.15 .038(6)$ (2016). Members are also barred from limiting the "implied contractual duty of good faith and fair dealing." Id.

259 Miss. CODE ANN. § 79-29-123(4) (2016).

260 See Colo. Rev. StAT. AnN. § 7-80-108(1.5) (West 2006).

261 Id.

262 See Unif. Ltd. Liab. Co. ACt § 103(b) (Unif. Law COMM’N 1996). (stating an operating agreement may not eliminate the loyalty duty or good faith obligation or "unreasonably reduce the duty of care," but may identify "activities that do not violate the duty of loyalty, if not manifestly unreasonable," and specify the vote necessary to approve the act or transaction "that otherwise would violate the duty of loyalty").

263 See id. (stating an operating agreement may not eliminate the loyalty duty or good faith obligation or "unreasonably reduce the duty of care," but may identify "activities that do not violate the duty of loyalty if not manifestly unreasonable," and specify the vote necessary to approve the act or transaction "that otherwise would violate the duty of loyalty." (emphasis added)).

${ }^{264}$ See id. 


\section{E. Exculpatory Approach}

Despite very similar language in the statutes for all six states providing only for exculpatory provisions covering breaches of fiduciary duties, ${ }^{265}$ there is no conformity in the case law of Connecticut, Kentucky, Louisiana, Michigan, New York and North Carolina. No case law exists for Kentucky and Michigan. Connecticut courts have not yet addressed the enforceability of a waiver in the LLC context, but they have been unfriendly toward waivers in the LP context. ${ }^{266} \mathrm{New}$ York courts have proven unfriendly toward waivers in the LLC context. ${ }^{267}$ North Carolina, in contrast, has enforced waivers in the LLC context despite the statutory language providing only for exculpation. ${ }^{268}$ Louisiana has enforced a waiver, but only in a single case that resulted in an unpublished opinion. ${ }^{269}$

The provisions in the Connecticut, Kentucky, Louisiana, Michigan, New York, and North Carolina statutes only provide for exculpation from monetary liability; equitable relief may still be available to aggrieved parties. ${ }^{270}$ Parties forming an LLC in a state only explicitly providing for exculpation may be able to contract for a waiver in effect with a provision in the operating agreement that all remedies are limited to monetary damages. ${ }^{271}$

\section{F. Final Analysis of the Statutory Text}

Statutory text gives the strongest argument for the enforceability of waivers. Only in one state-North Carolina - have the courts been more amenable to waiver of fiduciary duty by LLC members than the statutory text would lead an observer to believe. The statutory texts in the remaining states (with notable exceptions) at least provide an attorney a base from which to argue for the enforcement of a waiver so long as it does not fall within one of the statutory carve-outs. The inclusion of "elimination" in the several states' statutes leaves precious little room for an attorney to argue against enforceability outside of the difficult argument that the other side's actions violated the implied contrac-

265 See supra note 59 and accompanying text; see also RibSteIn \& KeAtinge, supra note 37. 266 See, e.g., Konover Dev. Corp. v. Zeller, 635 A.2d 798, 805 (Conn. 1994) (holding that the fiduciary duties of a general partner in an LP cannot be waived).

267 See, e.g., Pappas v. Tzolis, 982 N.E.2d 576 (N.Y. 2012).

268 See, e.g., Kaplan v. O.K. Techs., L.L.C., 675 S.E.2d 133, 140 (N.C. Ct. App. 2009) (interpreting the exculpatory provision of the North Carolina LLC Act as allowing the duties of members to be reduced by the operating agreement).

269 See Broussard v. Tipton, No. 2013 CA 1268, 2014 WL 3559371, at*1-2 (La. Ct. App. Apr. 24, 2014).

270 See, e.g., Solar Cells, Inc. v. True N. Partners, L.L.C., No. Civ.A. 19477, 2002 WL 749163 , at $* 4$ (Del. Ch. April 25, 2002) (finding a waiver of liability from any conflict of interest did not prevent injunctive relief).

271 The enforceability of such provisions is outside of the scope of this article. It should be noted, however, that a planning attorney should be, all else equal, less confident in the enforceability of a provision designed to effect something that the legislature has chosen not to expressly provide for in the statute. 
tual covenant of good faith and fair dealing, waiver notwithstanding. Unfortunately, Colorado and California have statutes so vague and ambiguous, respectively, that a planning attorney cannot with any certainty predict whether a waiver will be enforceable. The exculpatory provisions of some states also provide scant protection, although there is case law very favorable to the enforcement of waivers in North Carolina.

\section{ANALYSIS OF LP CASE LAW}

If LLC case law on-point is not available, ${ }^{272}$ it is instructive to turn to LP case law to better predict how a court will treat a particular provision. ${ }^{273}$ LLCs share a doctrinal foundation in contracts with LPs that corporations do not. ${ }^{274}$ Unfortunately, courts may look to LP law for guidance even where the applicable LLC statute takes a more liberal stance toward waiver of fiduciary duty than the applicable LP statute.

While courts have upheld waivers, there is no consensus regarding the enforceability of waivers in general partnerships. ${ }^{275}$ However, courts have enforced provisions in partnership agreements allowing partners to compete with the firm and allowing self-dealing. ${ }^{276}$ Courts have also interpreted provisions in LP agreements narrowly in order to avoid enforcing a waiver of fiduciary duties. $^{277}$

\section{A. Delaware Case Law}

Delaware courts have been very open to waivers of fiduciary duties in LPs. ${ }^{278}$ The Delaware Supreme Court upheld a provision setting the fiduciary

272 See supra note 227 and accompanying text (Alabama, Arkansas, Colorado, Connecticut, Kentucky, Maine, Maryland, Massachusetts, Michigan, Mississippi, New Hampshire, New Mexico, Washington, and Wisconsin).

273 See Wayne M. Gazur, The Limited Liability Company Experiment: Unlimited Flexibility, Uncertain Role, 58 LAW \& CONTEMP. PROBS. 135, 138 (1995) (positing that courts will rely heavily on analogies to more familiar entity forms in developing LLC case law); see also RIBSTEIN, supra note 3, at 143 (arguing one of the chief advantages of the LP form is the large body of legal precedent available).

274 See, e.g., RIBSTEIN, supra note 3, at 33.

275 Compare Wilson v. Button, 404 F.2d 309, 309 (5th Cir. 1968), Hooper v. Yoder, 737 P.2d 852, 853 (Colo. 1987), Covalt v. High, 675 P.2d 999, 999 (N.M. Ct. App. 1983), and Singer v. Singer, 634 P.2d 766, 767 (Okla. Ct. App. 1981), with Palmisano v. Mascaro, 611 So. 2d 632, 644 (La. Ct. App. 1992), and Lyall v. Grayco Builders, Inc., 584 N.Y.S.2d 465, 468-70 (N.Y. App. Div. 1992).

${ }^{276}$ Larry E. Ribstein, The Revised Uniform Partnership Act: Not Ready for Prime Time, 49 Bus. LAw. 45, 57 \& nn.93-94 (1993).

277 See Labovitz v. Dolan, 545 N.E.2d 304, 304-05 (Ill. App. Ct. 1989) (interpreting a term giving the general partner "sole discretion" in decision making as not waiving the fiduciary duties of the general partner).

278 See, e.g., Cincinnati SMSA Ltd. P'ship v. Cincinnati Bell Cellular Sys. Co., 708 A.2d 989, 993-94 (Del. 1998) (holding entrance by limited partner into the personal communications services market did not meet the narrow definition of "cellular service" and thus was 
duties of the general partner to mirror those that apply in the Delaware corporation law in Gotham Partners, L.P. v. Hallwood Realty Partners, L.P., ${ }^{279}$ but made a questionable assertion in dicta. The Delaware Supreme Court could not let a statement in the Vice Chancellor's decision stating that the Delaware LP Act "expressly authorizes the elimination, modification or enhancement of ... fiduciary duties in the written agreement governing the limited partnership" pass uncriticized. ${ }^{280}$ The court also noted a similar statement in Sonet $v$. Timber

governed by a waiver broadly allowing competition with the LP); Lonergan v. EPE Holdings L.L.C., 5 A.3d 1008, 1016-19 (Del. Ch. 2010) (refusing to substitute the implied covenant of good faith and fair dealing for fiduciary duty analysis where the LP agreement eliminated all fiduciary duties); Gelfman v. Weeden Inv'rs, L.P., 792 A.2d 977, 984-87 (Del. Ch. 2001) (interpreting facially inconsistent provisions of the LP as replacing the default objective fairness with a scienter-based standard of loyalty); Cantor Fitzgerald, LP v. Cantor, No. CIV.A. 18101, 2001 WL 1456494, at*4-6 (Del. Ch. Nov. 5, 2001) (holding distributions were made in accordance with the partnership agreement and thus were covered by waiver cleansing all decisions by the general partner made "in good faith and in accordance with the terms of the" partnership agreement); Kahn v. Icahn, No. CIV. A. 15916, 1998 WL 832629, at *3 (Del. Ch. Nov. 12, 1998) (refusing to interpret a provision of the LP agreement allowing direct competition as inapplicable to business usurpation); Sonet v. Timber Co., 722 A.2d 319, 324-26 (Del. Ch. 1998) (enforcing an LP agreement giving the general partner the "sole discretion" regarding decisions on extraordinary acts or transactions and allowing the general partner to not consider the interests of the limited partners in resolving conflicts of interest); In re Cencom Cable Income Partners, L.P. Litig., No. 14634, 1996 WL 74726, at *4-5 (Del. Ch. Feb. 15, 1996) (recognizing than an LP agreement can create a "safe harbor" for certain types or categories of transactions and holding that the transaction in question fell into such a contractually created safe harbor); In re Marriott Hotel Props. II Ltd. P'ship Unitholders Litig., No. 14961, 1996 WL 342040, at*6-7 (Del. Ch. June 12, 1996) (holding that any breach of fiduciary duties due to application Revlon duties was foreclosed by provisions in the LP agreement giving the general partner "absolute discretion" to veto the transfer of limited partnership units); Wilmington Leasing, Inc. v. Parrish Leasing Co., No. 15202, 1996 WL 752364, at*14-15 (Del. Ch. Dec. 23, 1996) (holding that removal of the general partner could not be a breach of fiduciary when done pursuant to a provision of the LP agreement so long as reasonable and in good faith); see also In re Scarff, No. 03-54723 ASW, 2010 WL 4052917 , at *5-8, 13 (Bankr. N.D. Cal. Oct. 14, 2010) (refusing to supplant contractually defined fiduciary duties with Delaware common law fiduciary duties); Aris Multi-Strategy Fund, L.P. v. Accipiter Life Scis. Fund II (QP), L.P., No. 601110-2009, 2010 WL 2033128 (N.Y. Sup. Ct. Jan. 21, 2010) (finding that fiduciary duties were modified sufficiently to defeat a breach of fiduciary duty claim by a "sole discretion" clause and an exculpatory clause); Barrett v. Toroyan, 813 N.Y.S.2d 415, 28 A.D. 331, 332 (App. Div. 2006) (holding that under Delaware law a provision of the LP agreement allowing general partner to engage in " "other businesses" " allowed those general partners "to pursue business opportunities that might otherwise have gone to the partnership"). But see Forsythe v. ESC Fund Mgmt. Co. (U.S.), Inc., No. 1091-VCL, 2007 WL 2982247, at *7-8 (Del. Ch. Oct. 9, 2007) (holding that waiver of the duty of loyalty in effect raised the duty of care); see also Venture Inv. Partners, L.L.C. v. JT Venture Partners L.L.C., No. 064353, 2007 WL 4098850, at *7 (Mass. Super. Ct. Oct. 25, 2007) (finding under Delaware law that the waiver in question did not cover the transactions alleged).

${ }^{279}$ Gotham Partners, L.P. v. Hallwood Realty Partners, L.P., 817 A.2d 160, 163-64 (Del. 2002).

${ }^{280}$ Id. at 167 (alterations in original) (quoting Gotham Partners, L.P. v. Hallwood Realty Partners, L.P., No. 15754, 2000 WL 1476663, at *10 (Del. Ch. Sept. 27, 2000)). 
Co. ${ }^{281}$ The statements in both cases were dicta rather than binding precedent, ${ }^{282}$ and that particular issue was not before the Delaware Supreme Court for review. ${ }^{283}$ That did not stop the court from stating that while it would be inappropriate for them "to express an advisory opinion on a matter not before" them, if they were expressing an advisory opinion it would be that the fiduciary duties of a general partner cannot be eliminated by contract. ${ }^{284}$ The court came to this conclusion through a dubious bit of statutory interpretation, admitting that "on its face Section 17-1101(d) [the statute] permits the fiduciary duty of a general partner to be expanded or restricted without limit by the terms of a partnership agreement." ${ }^{285}$ The court may have reasoned that the plain meaning of the statutory provision reflected poor draftsmanship by the Delaware legislature rather than its intent, or, most likely, both. The Delaware legislators promptly informed the Delaware Supreme Court that they did in fact mean what they originally wrote by amending both the Delaware LLC Act and LP Act to explicitly allow the elimination of fiduciary duties. ${ }^{286}$ Clearly the Delaware Supreme Court either misinterpreted the intentions of the Delaware legislature or failed to faithfully effect that intent.

\section{B. Maryland Case Law}

Maryland has also proven friendly to waiver in the LP context. The "Clancy" in Clancy v. King was Tom Clancy, the author of bestselling thrillers, including the Jack Ryan novels such as The Hunt for Red October and Patriot Games. ${ }^{287} \mathrm{He}$ formed a LP with his then wife, Wanda King, to "engage in activities relating to the writing, publishing and sale of books." ${ }^{288}$ Each held a 1 percent general partnership interest and a 49 percent limited partnership interest. ${ }^{289}$ The LP contracted with S \& R Literary, Inc., to form a joint venture to publish books under Clancy's name that had been ghostwritten by another author. ${ }^{290}$ When, after several books had been published, Clancy moved to have his name removed from the series, his now ex-wife King sued, alleging that he

281 Id. at 167 n.12 (citing Sonet v. Timber Co., 722 A.2d 319, 323 (Del. Ch. 1998) (stating that section 17-1101(d) "apparently [allows] broad license to enhance, reform, or even eliminate fiduciary duty protections")).

282 Id. at 167.

283 Id.

$284 I d$. at 168

285 Id. at 167 n. 13 (quoting Martin I. Lubaroff \& Paul M. Altman, Luberoff \& Altman ON Delaware Limited Partnerships $\S \S 11.2 .6,13.1 .2$ (1995 \& Supp. 2002)).

286 See Edwin W. Hecker, Jr., Fiduciary Duties in Business Entities, 54 U. KAN. L. REV. 975, 1019 (2006); see also Steele, supra note 231, at 10-14, 17 (discussing the evolution of the Delaware LP Act).

287 See Clancy v. King, 954 A.2d 1092, 1095 (Md. 2008).

288 Id.

289 Id.

${ }^{290} I d$. at $1095-96$. 
breached his fiduciary duty to her and the LP. ${ }^{291}$ The Court of Appeals (the Court of Appeals is the highest court in the Maryland court system) noted that Maryland law permitted LP agreements to modify the duty of loyalty and that such modifications had been enforced. ${ }^{292}$ The Court of Appeals reversed the decision of the trial court, holding that the LP agreement "clearly and unambiguously limits the duty of loyalty" owed by Clancy by explicitly allowing him to compete with the LP. ${ }^{293}$ The only remaining question, then, was whether Clancy exercised his discretion in good faith, an issue the Court of Appeals was unable to resolve on the record. ${ }^{294}$

\section{California Case Law}

California courts have addressed the enforceability of judicial waivers in LP agreements, first addressing the issue in BT-I v. Equitable Life Assurance Society of the United States. ${ }^{295}$ A California state appellate court held that fiduciary duties cannot be contracted away through the LP agreement. ${ }^{296}$ BT-I, a general partnership, entered into a general partnership to develop commercial real estate with Equitable. ${ }^{297}$ Six years into the project, the parties replaced the original general partnership with an LP. ${ }^{298}$ BT-I was the limited partner and held a minority stake. ${ }^{299}$ The LP agreement gave the general partner, Equitable, broad powers and removed any responsibility of the general partner to prevent any lender from exercising remedies pursuant to a loan made to the LP. ${ }^{300} \mathrm{In}$ an effort to squeeze out BT-I, Equitable arranged with the LP's primary lender to purchase its loans to the LP. ${ }^{301}$ Equitable ostensibly offered the opportunity to purchase the loan to the LP, but neither the LP nor BT-I had the funds to purchase the loans, and unbeknownst to BT-I, the lender had secretly agreed to allow Equitable to match the highest bidder. ${ }^{302}$ Equitable subsequently refused to refinance the project and foreclosed on the property. ${ }^{303}$

BT-I sued Equitable for, among other things, breach of fiduciary duties. ${ }^{304}$ In characterizing the relationship between BT-I and Equitable, the court refer-

291 Id. at 1097.

292 Id. at 1100-01 (citing MD. CODE ANN., CORPS. \& Ass'NS § 9A-103(b)(3)(i); Della Ratta v. Larkin, 856 A.2d 643, 652-53 (Md. 2004)).

293 Id. at 1101.

294 Id. at 1106, 1109.

295 BT-I v. Equitable Life Assurance Soc'y of the U.S., 89 Cal. Rptr. 2d 811, 811 (Ct. App. 1999).

296 Id. at 816.

${ }^{297}$ Id. at $813-14$

298 Id. at 814 .

299 Id.

${ }^{300} \mathrm{Id}$.

$301 \mathrm{Id}$.

302 Id.

303 Id.

304 Id. at 815. 
enced partnerships with no effort to distinguish between a general partnership and an LP. ${ }^{305}$ The California Revised Limited Partnership Act ${ }^{306}$ at that time gave partners in an LP freedom to contract around many default provisions, ${ }^{307}$ but with important limits. ${ }^{308}$ Relying on decisions from other states, the court held the purchase of the debt was a breach of fiduciary duty. ${ }^{309}$ Relying on a general partnership case, AB Group v. Wertin, the court held that a waiver of fiduciary duties in an LP agreement is unenforceable. ${ }^{310}$ While the court in Wertin declined to void the waiver in question, explaining that only fiduciary obligations that are fundamental to the relationship between the parties cannot be waived, the court in BT-I extended the Wertin court's reasoning, finding the relationship between BT-I and Equitable fundamental and refusing to enforce the waiver. ${ }^{311}$ The court specifically discussed Labovitz v. Dolan, in which an Illinois court chose to interpret a provision giving the general partner "sole discretion" over the management of the LP as an unenforceable waiver, rather than narrowly interpreting the provision as not affecting fiduciary duties. ${ }^{312}$

The BT-I court was clear that the provision could not have been written in such a way as to cleanse the transaction in question, implying that it would interpret a waiver of fiduciary duty narrowly. ${ }^{313}$ In a statement showing a strong suspicion toward freedom of contract, the court went on to insist that "the fact that the act allows the parties to structure many aspects of their relationship is not a license to freely engage in self-dealing - it remains [the court's] responsibility to delimit the outer bounds of permissible conduct by a fiduciary" (note that the court implicitly claims control over defining who is in a fiduciary relationship with whom in order to limit the scope of permissible contractual definition by partners in an LP). ${ }^{314}$ The court also likely felt that the discretion given to Equitable to respond to lender actions was intended to protect Equitable from being forced to put more money into the venture, not to give it a path by which it could squeeze out minority investors.

305 See id. ("Partnership is a fiduciary relationship, and partners are held to the standards and duties of a trustee in their dealings with each other.").

306 See CAL. CORP. CODE $§ 15611$ (West 2005) (repealed 2010).

307 Id. $\S 15618$ (repealed 2010).

308 Id. $\S 15643$ (repealed 2010).

309 BT-I, 89 Cal. Rptr. 2d at 815-16 (relying on Wartski v. Bedford, 926 F.2d 11, 20 (1st Cir. 1991) (applying Massachusetts law); Konover Dev. Corp. v. Zeller, 635 A.2d 798, 808 (Conn. 1994); Thomas v. Schmelzer, 796 P.2d 1026, 1032-33 (Idaho Ct. App. 1990); Labovitz v. Dolan, 545 N.E.2d 304, 310, 313 (Ill. App. Ct. 1989); Dean Operations, Inc. v. One Seventy Assocs., 896 P.2d 1012, 1021-22 (Kan. 1995); Appletree Square I Ltd. P'ship v. Investmark, Inc., 494 N.W.2d 889, 893 (Minn. Ct. App. 1993); Ebest v. Bruce, 734 S.W.2d 915, 922 (Mo. Ct. App. 1987)).

${ }^{310}$ Id. at 816 (relying on AB Group v. Wertin, 69 Cal. Rptr. 2d 652 (Ct. App. 1997)).

311 Id.

312 Id. (quoting Labovitz, 545 N.E.2d 304).

$313 \mathrm{Id}$. at 817.

${ }^{314}$ Id. at 817-18. 
The California courts reaffirmed the approach taken in BT-I in Woodson $v$. Legacy Partners 2323 L.P. ${ }^{315}$ Legacy Partners 387 L.P. (LP 387) was an equal partner in a partnership. ${ }^{316}$ That partnership later became a general partner in a California LP organized to purchase and develop real estate in San Francisco. ${ }^{317}$ The general partners of LP 387 refinanced the debt for the development owned by the LP in order to prevent foreclosure and, in doing so, bought out their original partner's partnership interest. ${ }^{318}$ The general partners then organized a new LP, Legacy Partners 2323 L.P., to own the development. ${ }^{319}$

Woodson, a limited partner of LP 387, sued for breach of fiduciary duty, alleging the new structure gave additional benefits to the general partners of LP 387 at the expense of the limited partners. ${ }^{320}$ In its defense, the LP argued the refinancing was authorized by the LP agreement as a justifiable exercise of the general partners' business judgment, ${ }^{321}$ which is a bit odd, as the California Corporations Code appears to hold corporate directors to a stricter statutory default standard than partners. ${ }^{322}$ The court avoided application of the business judgment rule by explaining that, under California law, the rule only applies to corporations and not to LPs. ${ }^{323}$ The court instead looked to a "fiduciary duty of good faith and fair dealing" found in the code. ${ }^{324}$ There is an inherent confusion created by a statutory fiduciary duty borrowing terms of art directly from the contract law concept of an implied covenant of good faith and fair dealing. That confusion was exacerbated by an explanation of the duty of good faith, which appeared to incorporate the business judgment rule, immediately subsequent to disavowal of the business judgment rule by the court. ${ }^{325}$

315 Woodson v. Legacy Partners 2323 L.P., No. A100627, 2003 WL 22795886, at *4 (Cal. Ct. App. Nov. 25, 2003).

316 Id. at $* 1$.

317 Id.

318 Id.

319 Id.

${ }^{320} \mathrm{Id}$.

321 Id.

322 Compare CAL. CORP. CODE § 309(a) (West 2014) ("A director shall perform the duties of a director ... with such care ... as an ordinarily prudent person in a like position would use under similar circumstances."), with id. § 16404(c) (“A partner's duty of care . . . is limited to refraining from engaging in grossly negligent or reckless conduct, intentional misconduct, or a knowing violation of law.").

323 Woodson, 2003 WL 22795886, at *2 (relying on Lamden v. La Jolla Shores Clubdominium Homeowners Ass'n, 21 Cal. 4th 249, 259-60 (Ct. App. 1999)).

${ }^{324} I d$. at *3. The current version of this "duty" is housed in section 16404 of the California Corporations Code. See CAL. CoRP. CODE § 16404(d) (West 2014) ("A partner shall discharge the duties to the partnership and other partners under this chapter or under the partnership agreement and exercise any rights consistently with the obligation of good faith and fair dealing.").

325 See Woodson, 2003 WL 22795886, at *3 ("These characteristics-limited investor liability, delegation of authority to management, and fiduciary duty owed by management to investors - are similar to those existing in corporate investment, where it has long been the rule that directors are not liable to stockholders for mistakes made in the exercise of honest 
Satisfied that they had made everything perfectly clear, the court stated the issue was a question of fact that must be resolved at trial and moved on to the LP's defense that the actions of the general partners were permitted by the operating agreement. ${ }^{326}$ Relying on $B T-I$, the court found that the refinancing was a matter "fundamentally related to the partnership business" and hence could not be protected from judicial scrutiny by waiver. ${ }^{327}$ While the LP agreement adopted a "kitchen sink" approach to waiving duties, ${ }^{328}$ there is nothing in the language of the opinion to suggest that any wording would evade a judge's veto power. It should be noted that the court relied on judge-made law from $B T-I$, while making no attempt to reconcile the waiver in the LP agreement with the provision of the LP Act governing modification of fiduciary duties. While the court in $B T-I$ failed to undertake a full statutory analysis, there is no reason to expect a court to give close scrutiny to even a poor decision by a peer court when the reviewing court is not at liberty to reverse the precedent.

With negative LLC case law, a confused statutory approach, and negative LP case law, there is little hope for the enforcement of a waiver of fiduciary du-

business judgment, or for losses incurred in the good faith performance of their duties when they have used such care as an ordinarily prudent person would use . . , a general partner may not be held liable for mistakes made or losses incurred in the good faith exercise of reasonable business judgment." (alteration in original) (citations omitted) (quoting Wyler v. Feuer, 149 Cal. Rptr. 626, 632-33 (Ct. App. 1978))); id. ("[T]he presumption created by the business judgment rule can be rebutted . . . by affirmative allegations of fact which, if proven, would establish fraud, bad faith, overreaching or an unreasonable failure to investigate material facts." (second alteration in original) (quoting Lee v Interinsurance Exch., 57 Cal. Rptr. 2d 798, 811 (Ct. App. 1996))).

326 Id. at *3-4.

327 Id. at *4 (quoting BT-I v. Equitable Life Assurance Soc'y of the U.S., 89 Cal. Rptr. 2d 811, 816 (Ct. App. 1999)).

328 See id. at *4 n.4 ("The LP 387 partnership agreement gave any one of the managing general partners the powers 'to make all decisions with respect to the business and affairs of the Partnership and to take such action for and on behalf of the Partnership as he may deem necessary or appropriate to enable the Partnership to carry out its purpose,' including: '(a) to borrow money for and on behalf of the Partnership upon such terms and conditions as he, in his sole discretion, deems necessary or appropriate; [and][ๆ] (b) (in order to secure any loans to the Partnership ... or for Partnership purposes) to convey, mortgage, pledge, hypothecate, for and on behalf of the Partnership and upon such terms and conditions as he, in his sole discretion, deems necessary or appropriate, all or any part of the Partnership assets. . .' Additionally, "[e]ach partner, in his individual capacity or otherwise, [was] ... free to engage in, to conduct or to participate in any business or activity whatsoever, including, without limitation, the acquisition, development, management and exploitation of real property, without any accountability, liability or obligation whatsoever to the Partnership or to any other Partner, even if such business or activity competes with or is enhanced by the business of the partnership. Further, the General Partners, in the exercise of their power and authority under this Agreement, may contract and otherwise deal with or otherwise obligate the Partnership to entities in which any one or more of the Partners may have an ownership or other financial interest.' Under the agreement, the general partners had no liability to either the Partnership or any other partner 'for any error of judgment or for any mistakes of fact or law or for anything which they may do or refrain from doing hereafter in connection with the business and affairs of the Partnership except in the case of willful misconduct or gross negligence." "). 
ty under California law. LP case law only bolsters the approach, hostile to waiver, taken in Writer. ${ }^{329}$

\section{Connecticut Case Law}

While Connecticut courts have not addressed whether members of an LLC can contract out of fiduciary duties, they have analogized LLCs to LPs for the purposes of applying fiduciary duties. ${ }^{330}$ The Connecticut Supreme Court answered the question for partners in a LP in its 1994 decision, Konover Development Corp. v. Zeller. ${ }^{331}$ The parties and another investor formed a Connecticut LP in order to build a shopping mall, with Konover serving as the general partner. ${ }^{332}$ The parties were left as the sole investors in the venture and as equal partners after the other investor sold his interest to Zeller. ${ }^{333}$ Rapidly rising property values led to a disagreement among the parties over the price the LP would pay for a parcel of property owned by Zeller and over whether to abandon development in order to reap an immediate profit from the increased property values. ${ }^{334}$ The parties amended the LP agreement to give Konover the right to terminate the LP if, at its sole discretion, it determined the project was no longer feasible. ${ }^{335}$ Subsequently, Zeller would own all assets of the LP but would be liable to Konover for all of its "out-of-pocket" expenditures. ${ }^{336}$ After a series of setbacks, Konover terminated the LP and requested reimbursement for $\$ 1.1$ million in expenses. ${ }^{337}$

Konover sued to force payment of the requested reimbursement, and Zeller filed a counterclaim alleging breach of fiduciary duty. ${ }^{338}$ On appeal, Zeller specifically argued that, despite the "sole discretion" language in their agreement, Konover should have been held to the heightened standard imposed on a fiduciary in determining that the project was no longer feasible. ${ }^{339}$ The trial judge instructed the jury that Konover must merely have been acting "reasonably." 340

329 See USAT Reorganization L.L.C. v. Writer, No. D043230, 2004 WL 2538848 (Cal. Ct. App. Nov. 10, 2004).

330 Savanna Inv'rs, L.L.C. v. Vaughn, No. X08CV084012896S, 2008 WL 4021333, at *6 n.6 (Con. Super. Ct. July 30, 2008).

331 Konover Dev. Corp. v. Zeller, 635 A.2d 798 (Conn. 1994).

332 Id. at 800 .

333 Id.

334 Id.

335 Id. at 801.

${ }^{336} \mathrm{Id}$.

337 Id. at 802.

338 Id.

339 Id.

${ }^{340} I d$. at 803 n. 7 The jury instructions provided in part:

The exercise by the plaintiff of the contractual right it bargained for and obtained would not be a breach of its duty under the contract, provided the decision was made reasonably based upon a careful review of the relevant information the general partner had before it. 
Konover's argument that the agreement gave it sole discretion to terminate the partnership fell on deaf ears, and the court refused to characterize the claim as a breach of contract dispute. ${ }^{341}$ The court took advantage of poor lawyering by Konover's attorney and refused on procedural grounds to determine whether the Connecticut LP Act allowed such a waiver. ${ }^{342}$ Were the court to have examined the statute, it would have discovered language that implied indirectly that fiduciary duties could be modified by the LP agreement. ${ }^{343}$

The court appeared to see no conflict between its statement that the exercise of Konover's fiduciary duty "was to be viewed in light of all of the facts of the case" 344 and the fact that Konover and Zeller had bargained at arms' length to give Konover the discretion to terminate the partnership. The court claimed to take a "middle ground" between contractual freedom and respect of the fiduciary relationship, ${ }^{345}$ but it is difficult to reconcile the court's refusal to enforce the contractual provision in question with any sort of middle ground. Konover attempted to rely on an Illinois case, but the court distinguished it on the basis that the breach occurred when the parties were at arms' length. ${ }^{346}$ However, it is the relationship of the parties at the time of contract formation, not breach, that should govern as a matter of application of contract law doctrine, and Konover and Zeller were at arms' length at the time the LP agreement was revised. ${ }^{347}$

Further eroding its earlier reference to a middle ground, the court added that "in circumstances such as these," the state's interest in freedom of contract did not deserve as much deference as its interest in maintaining a fiduciary relationship. ${ }^{348}$ The court gave no guidance as to what type of waiver would be enforced, and indeed no solace that any waiver would pass muster. It is also worth noting that neither of the cases relied upon by the court are from a jurisdiction allowing waiver by LLC members and one of the cases, despite being identified

\footnotetext{
... If you find that the agreement was that the plaintiff had sole discretion to terminate the project and exercised that discretion, reasonably you would find that the plaintiff did not violate its fiduciary duty. Id. 
as such, was not an LP case at all. ${ }^{349}$ The court felt no need to examine the statutory text in balancing between the threat that "an overly strict interpretation of partnership loyalty might stifle the limited partnership form" and the threat that an active general partner might take advantage of a passive limited partner, giving greater weight to the latter. ${ }^{350}$ The court likely felt Zeller could not have intended to give Konover license to act unreasonably, and the court may have also seen the fiduciary duty claim as a way to hold Konover accountable for a request for reimbursement of expenses that they felt were unreasonable.

A Massachusetts court, interpreting Connecticut law, felt confident enough in the development of the case law post-Zeller to avoid enforcing a waiver provision in a Connecticut LP agreement in Sizemore v. I-R Maple Corp. ${ }^{351}$ After detailing an extremely complicated set of facts, ${ }^{352}$ the court addressed the claim for breach of fiduciary duty. The court applied the "Zeller standard of fairness" test applicable to a complex commercial relationship between sophisticated parties. ${ }^{353}$ Noting the addition in Spector v. Konover of a requirement of the consent of the limited partners supposedly implicit in the Zeller test, ${ }^{354}$ the court rejected the defendants' argument that the waiver provided prior consent for the transaction, stating, "In general, the terms of a limited partnership agreement cannot negate the fiduciary duty between partners." 355 While the court saw Connecticut law as unclear as to how, or even if, the Zeller test should be applied, it clearly did not see the Zeller test as leaving room for a waiver to foreclose judicial scrutiny and veto. ${ }^{356}$ The "middle ground" approach of Zeller clearly still stands well outside of the Delaware approach. ${ }^{357}$

A Connecticut court did, however, finally find some room for a waiver of fiduciary duties in Merrick v. Cummin. ${ }^{358}$ Merrick, a limited partner in a Delaware LP that was organized to own venture capital investment funds, ${ }^{359}$ sought relief for a usurpation of a business opportunity by the general partners. ${ }^{360}$ Mer-

349 See id. (relying on Wartski v. Bedford, 926 F.2d 11 (1st Cir. 1991) (stating fiduciary duties in a general partnership cannot be waived); Labovitz v. Dolan, 545 N.E.2d 304 (Ill. App. Ct. 1989)).

$350 I d$. at 809 (deciding that "wise public policy counsels the retention of the fiduciary principle").

351 Sizemore v. I-R Maple Corp., No. 012773, 2003 WL 21246178, at *9 (Mass. Super. Ct. April 28, 2003)

352 Id. at $* 1-5$.

353 Id. at *7.

354 Id. at *7-8 (relying on Spector v. Konover, 747 A.2d 39, 44 (Conn. App. Ct. 2000)).

355 Id. at $* 8$.

356 Id. at *8-9.

357 See, e.g., Cavolick v. DeSimone, No. X03CV990501611S, 2003 WL 21976911, at *5-6 (Conn. Super. Ct. July 30, 2003) (dismissing the waiver provision of the LP as "not surprising"- and ineffective - given the larger investment and risk taken on by the general partner).

358 Merrick v. Cummin, 919 A.2d 495 (Conn. App. Ct. 2007).

359 The LP was organized under Delaware law, but the court applied Connecticut law. Id. at 498 n.3.

360 Id. at 497. 
rick, however, had contractually agreed in settlement of an earlier arbitration proceeding not to bring any future arbitration proceeding. ${ }^{361}$ The arbitrator found that the earlier agreement barred Merrick from challenging the transaction in question, and Merrick asked the court to vacate the ruling as void against Connecticut public policy because it amounted to a waiver of fiduciary duties. ${ }^{362}$ The court refused Merrick's request, noting that both parties were equally sophisticated businesspeople and finding no clear public policy "against the voluntary waiver of future claims concerning breach of that [fiduciary] duty." ${ }^{" 363}$ The court made only a cursory reference to Zeller and dismissed it, along with other cases voiding various types of waivers as factually distinguishable. ${ }^{364}$ The court made no effort to apply the reasoning of Zeller to the facts of the case.

The court's decision in Merrick is difficult to reconcile with Zeller, and it is unclear whether it is an aberration; a special, narrow rule; or indicative of a new openness to waivers of fiduciary duties in Connecticut courts. ${ }^{365}$ The openness to waiver in Merrick was likely due at least in part to the extremely sophisticated parties involved. Without any LLC case law on-point, the confusion in the LP case law created by Merrick leaves the enforceability of waiver of fiduciary duty very uncertain under Connecticut law.

\section{E. Massachusetts Case Law}

Prior to the enforceability of a waiver of fiduciary duty being upheld (in the LLC context) in Pointer, ${ }^{366}$ the leading case on waiver of fiduciary duties in Massachusetts business associations had long been an LP case, Wartski v. Bedford.$^{367}$ The partnership at issue in Wartski fell into the familiar scenario of an inventor teamed up with a business-savvy deep pocket. ${ }^{368}$ Wartski and Bedford partnered to develop and market a data collector for motor vehicles that Wartski had invented. ${ }^{369}$ The venture was formally organized as a Massachusetts LP, with Wartski and Bedford as general partners and two other experts involved in the project as limited partners. ${ }^{370}$ The sole asset of the LP was a newly formed corporation, to which the LP transferred Wartski's invention. ${ }^{371}$

361 Id.

362 Id. at 497-98.

363 Id. at 499.

364 Id.

365 But see Hartley v. Boyd, No. X02CV034004679SCLD, 2008 WL 442142, at*11 (Conn. Super. Ct. Feb. 04, 2008) (reiterating that fiduciary duties cannot be waived and applying the Zeller test with no discussion of Merrick).

366 Pointer v. Castellani, 918 N.E.2d 805, 821 (Mass. 2009).

367 Wartski v. Bedford, 926 F.2d 11 (1st Cir. 1991).

${ }^{368} \mathrm{Id}$. at 14-15.

369 Id. at 14.

$370 \mathrm{Id}$. at 15.

371 Id. 
The corporation had some initial success attracting equity financing from investors but struggled nonetheless, leading to a dispute between Wartski and Bedford, which culminated in Wartski leaving employment with the corporation (although he remained a general partner of the LP and director of the corporation). ${ }^{372}$ Bedford later offered to buy-out the outside investors at a nominal sum when the corporation reached the point of insolvency. ${ }^{373}$ Bedford pushed ahead with his plan over Wartski's protests that the shares be shared with the LP, telling him: "That was life in the big city." 374 Bedford was able to successfully gain control of the corporation over a period of time for around ten dollars and eventually negotiated its sale for over one million dollars. ${ }^{375}$

Wartski sued Bedford for breach of fiduciary duty owed to Wartski as a result of the LP relationship. ${ }^{376}$ Wartski argued that Bedford had violated his duty to offer the business opportunity to purchase the shares of the outside investors at a nominal sum. ${ }^{377}$ Bedford countered by arguing the LP agreement authorized his actions. ${ }^{378}$ The LP agreement contained an extremely broad waiver permitting the general partners to compete directly with the LP. ${ }^{379}$ The court went so far as to admit that the contractual language may have cleansed Bedford's actions, but held the provision was ineffective as a waiver of fiduciary duty. ${ }^{380}$ The court failed to engage in any interpretation of statutory text or to cite to a single case interpreting Massachusetts law (or to any case interpreting another state's law discussed in this article). ${ }^{381}$ The court saw Bedford as using the agreement to take advantage of Wartski, but the court failed to take into account that Wartski did not do everything he could to protect his contractual rights. For example, Wartski never hired an attorney and did not make an offer to the other investors to counter Bedford's offer. ${ }^{382}$ While the court made sure to note that Wartski relied upon Bedford's superior knowledge of and experience in business and financing, ${ }^{383}$ its holding left no room for sophisticated par-

372 Id.

$373 I d$. at 16.

374 Id.

375 Id. at $17-18$.

$376 \mathrm{Id}$. at 12.

377 Id. at $18-19$.

378 Id. at $18-20$.

379 Id. at 20 ("Section 5.4 of the agreement states: 'General Partners shall not be prevented from engaging in other activities for profit, whether in research and development or otherwise, and whether or not competitive with the business of the partnership.' ").

$380 I d$. ("[E]ven if the partnership agreement can be interpreted as [Bedford] claims, it cannot nullify the fiduciary duty owed by Bedford to the partnership. The fiduciary duty of partners is an integral part of the partnership agreement whether or not expressly set forth therein. It cannot be negated by the words of the partnership agreement.").

381 See id. (first citing Labovitz v. Dolan, 545 N.E.2d 304, 310 (Ill. App. Ct. 1989); and then citing Irwin v. West End Development Co., 342 F. Supp. 687, 701 (D. Colo. 1972), aff'd in part and rev'd in part on other grounds, 481 F.2d 34 (10th Cir. 1973)).

382 Id. at $16-17$.

383 Id. at 20. 
ties to waive fiduciary duties. Under the highly questionable reasoning of Wartski, Massachusetts courts would retain the power to veto contractual provisions years after the contract was signed.

\section{F. Final Analysis of LP Case Law}

Seven states remain without case law guidance in either the LLC or LP context. ${ }^{384}$ One state - California - has negative case law for waivers in both the LLC and LP context. Taken together with the statutory ambiguity in California, and the subsequent repeal of both the LLC and LP Acts, it seems clear that a waiver will not be enforced. Connecticut has well established negative case law in the LP context, no case law in the LLC context, and offers only scant statutory protection, so the same can likely be said for Connecticut. However, Merrick shows that Connecticut courts may not be entirely hostile to waivers if they are confident that both parties are equally sophisticated. ${ }^{385}$ While the decision in Pointer ${ }^{386}$ (an LLC case) and the statutory text would appear to provide ample support for the enforceability of a waiver of fiduciary duties in Massachusetts, courts are likely to still find Wartski highly persuasive. The LP case law for Delaware tracks the approach of Delaware LLC case law-strongly supporting the freedom to contract. The dicta in Gotham Partners indicating that a provision completely eliminating fiduciary duties would not be enforced ${ }^{387}$ has been nullified by statute..$^{388}$

\section{MACRO IMPLICATIONS}

The current state of the law raises a number of concerns. The statutes in many states are detrimental to economic growth and are unlikely to meet the interests of state legislatures. Judges have exacerbated these statutory failings by sometimes interpreting the applicable LLC act poorly and inconsistently.

Part A calls for state legislatures to address contradictions and ambiguities in the LLC statutes on the books. Part B calls for judges to faithfully apply provisions of the applicable LLC statues providing for waiver of fiduciary duties, arguing for judicial fidelity for policy reasons specific to both statutory construction and to the nature of contracts in general and as they operate in the LLC context.

\footnotetext{
384 Alabama, Arkansas, Colorado, Kentucky, Maine, Michigan, Mississippi, New Mexico, Washington, and Wisconsin.

385 See Merrick v. Cummin, 919 A.2d 495, 499-500 (Conn. App. Ct. 2007). But see Hartley v. Boyd, No. X02CV034004679, 2008 WL 442142, at*11 (Conn. Super. Ct. Feb. 04, 2008) (reiterating that fiduciary duties cannot be waived and applying the Zeller test with no discussion of Merrick).

386 Pointer v. Castellani, 918 N.E.2d 805, 819-21 (Mass. 2009).

387 See Gotham Partners, L.P. v. Hallwood Realty Partners, L.P., 817 A.2d 160, 168 (Del. 2002).

388 See Del. Code AnN. tit. 6, § 18-1101(c) (2016).
} 


\section{A. Legislative Implications}

Legislatures seeking to promote business and discourage unnecessary litigation should ensure clear guidance on waiver of fiduciary duties in their LLC act. They should avoid forcing courts to reconcile multiple sections of the LLC act to infer an endorsement of a waiver (e.g., the indirect approach), and they should avoid the use of vague terms such as "manifestly unreasonable" (e.g., the Colorado LLC $\mathrm{Act}^{389}$ ). A provision directly allowing waiver is also preferable to only an exculpation provision, unless the legislature does in fact intend only to provide relief from monetary damages while preserving equitable remedies.

State legislatures can facilitate value-added investment by providing certainty as to the enforceability of waivers of fiduciary duties in their LLC statutes. States compete to attract business associations by the most efficient commercial laws ${ }^{390}$ and stand to benefit tremendously from clear rules allowing broad waiver of fiduciary duties. It is not the proper role of the state to attempt to serve as a moral arbiter of how sophisticated parties define their own, freely entered business relationships. Sophisticated parties are better equipped than the state legislature to plan value-maximizing transactions and to protect themselves from rapacious behavior by the other party (including balancing the risk of such behavior versus the cost of taking protective steps).

Even opponents of enforcing waivers of fiduciary duties recognize that there is a call for flexibility through private ordering. ${ }^{391}$ While both legislatures and courts suffer from institutional problems of "generality and stasis," and create rules that tend to stay past their welcome, ${ }^{392}$ legislatures are best suited to answering that call. Judicial decisions have been slow in coming; ${ }^{393}$ legislative change has not. ${ }^{394}$ The availability and representative heuristics are less problematic for legislatures than courts: legislatures see all stages of the LLC lifecycle, not just disputes and failures. Further, the LLC is a creation of statute, not common law; that is, the "ancient judicial prerogative of making the law" has been abrogated. ${ }^{395}$

389 Colo. Rev. Stat. AnN. § 7-80-108(1.5) (West 2006).

390 See, e.g., Ralph K. Winter, Jr., State Law, Shareholder Protection, and the Theory of the Corporation, 6 J. Legal Stud. 251, 254-62 (1977). See generally John Armour et al., Is Delaware Losing Its Cases?, 9 J. EMPIRICAL LeGAL StUD. 605 (2012).

391 See Miller supra note 8, at 613 ("There is clearly a call for legislation that permits a considerable degree of contractual modification.").

392 Butler \& Ribstein, supra note 16, at 57.

393 See supra Part II.

394 At least five states (Idaho, California, New Jersey, North Carolina, and Kansas) have amended or replaced the provisions in their respective LLC Acts pertaining to waiver of fiduciary duties.

395 Antonin Scalia \& Bryan A. Garner, Reading Law: The Interpretation of Legal TEXTs 3-4 (2012) ("Such distortion of texts that have been adopted by the people's elected representatives is undemocratic. In an age when democratically prescribed texts (such as 


\section{B. Judicial Implications}

Courts should apply the plain meaning of the statutory text. The legislature's intent in enacting a statute is neither discernable nor, frankly, anything other than a fiction. ${ }^{396}$ Statutes represent a truce between warring factionscourts should not advance the interests of a single side of that debate. ${ }^{397}$ Judges should interpret statutes much as they do contracts, by examining the words of the statute simultaneously and in conjunction with each other, without adding or subtracting unnecessary implied terms. ${ }^{398}$ A "canon of construction" in favor of fiduciary duties has no place where the text of the statute and the agreement provide for modification. ${ }^{399}$ Judges are not businesspeople, and their core competency is not evaluating ex ante decision-making post hoc. It is instructive that the judges with presumably the greatest understanding of business, the chancellors of the Delaware Court of Chancery, are quick to uphold business decisions. ${ }^{400}$ Courts in all states will look beyond the agreement when principles of equity are implicated, but the specialized Court of Chancery is much less apt to do so. Unfortunately, even if judges in some of these states do strive to follow the text, some statutes are so ambiguous or vague that it may not be entirely clear that a waiver should be enforced.

A breach of fiduciary duty cannot occur unless there is a fiduciary relationship between the parties. ${ }^{401}$ If a contractual waiver prevents that relationship from forming, then there can be no future breach. Traditionally fiduciary duties are created when one party is in a position of dominance over another party. ${ }^{402}$

[LLC Acts]) are the rule, the judge's principle function is to give those texts their fair meaning.").

396 See id. at 369-96.

397 See Frank H. Easterbrook, The Role of Original Intent in Statutory Construction, 11 HARV. J.L. \& PUB. POL'Y 59, 63 (1988) (noting that statutes are "born of compromise").

398 See id. at 60 (arguing that statutes are public documents that "should be read, like a contractual offer, to find their reasonable import"). See generally SCALIA \& GARNER, supra note 399.

399 See Butler \& Ribstein, supra note 16, at 31 (criticizing such a recommendation). Several states (e.g., Delaware, New Mexico) explicitly provide for giving "maximum effect to the principle of freedom of contract and to the enforceability of operating agreements of limited liability companies," but such provisions are superfluous if proper principles of statutory interpretation are followed. N.M. STAT. ANN. § 53-19-65 (West Supp. 2015); accord JOHN M. Cunningham \& Vernon R. Proctor, Drafting Limited Liability Company Operating AgreEMENTs 2-13 (3d ed. 2016) (quoting Del. Code ANN. tit. 6, § 18-1101(b) (2016)).

400 On at least one occasion the Delaware Supreme Court has shown itself to be more skeptical than the Court of Chancery. See Gotham Partners, L.P. v. Hallwood Realty Partners, L.P., 817 A.2d 160, 168 (Del. 2001) (stating in dicta that an elimination of fiduciary duties in the LP agreement would not be enforced).

401 See, e.g., Kaplan v. O.K. Techs., L.L.C., 675 S.E.2d 133, 141 (N.C. Ct. App. 2009) (“[I]t is fundamental that a fiduciary relationship must exist between the parties in order for a breach of fiduciary duty to occur." (alteration in original) (citing Branch v. High Rock Realty, Inc., 565 S.E.2d 248, 253 (N.C. Ct. App. 2002))).

402 Arthur B. Laby, Resolving Conflicts of Duty in Fiduciary Relationships, 54 AM. U. L. REv. 75, 77 n.2 (2004) ("Fiduciary duties are said to arise as a constraint on opportunism 
Absent undue influence or some other factor that would defeat the contract, this relationship does not exist at the time of contract formation. Hence, a contractual waiver of fiduciary duties should be viewed through the prism of a contractual relationship, not of a fiduciary relationship. ${ }^{403}$ "The general rule of contract law is that if a written contract exists, the parties' rights are controlled by that contract." 404

Freedom of contract should be promoted as it leads to economic efficiency gains. Sophisticated parties are better equipped to protect their own interests than are judges; they possess greater knowledge of business in general and of the transaction at hand, and have a larger stake in its result. ${ }^{405}$ Nonsophisticated parties can protect themselves contractually (the waiver is, after all, an opt-out provision) or through more protective entity forms such as a partnership or corporation (especially in states providing additional protections to shareholders in a closely held corporation). If fiduciary duties are merely a response to the difficulties of addressing such obligations by contract, ${ }^{406}$ then it follows that if parties are able to address those obligations in their contract, the need for court-imposed fiduciary duties is not present. "[W]hen parties fail to address a future state of the world - and they necessarily will because contracting is costly and human knowledge imperfect - then the elimination of fiduciary duties implies an agreement that losses should remain where they fall." ${ }^{407}$ Freedom of contract also helps provide the certainty that businesspeople so desperately seek from the law.

Even setting aside the general benefits of freedom of contract discussed above, enforcing contractual provisions eliminating fiduciary duties is beneficial, particularly given the tremendous variety in management structures facilitated by the LLC. ${ }^{408}$ A waiver of the duty of loyalty may allow parties to recruit members with significant expertise but conflicting interests. A notable example

presented to the fiduciary by virtue of the power or authority he receives from the principal.").

403 See Elizabeth S. Miller \& Thomas E. Rutledge, The Duty of Finest Loyalty and Reasonable Decisions: The Business Judgment Rule in Unincorporated Business Organizations?, 30 DEL. J. CORP. L. 343, 380-87 (2005) (arguing for the use of a contract model rather than a fiduciary model for applying waivers of fiduciary duty).

404 Mitchell Co. v. Campus, No. 08-0342-KD-C, 2009 WL 3527744, at*7 (S.D. Ala. Oct. 23, 2009).

${ }^{405}$ It should be presumed that parties entering into a flexible, contractual business association such as an LLC are sophisticated and in a better position than a court to make decisions in their own best interests. See supra Introduction.

406 See Easterbrook \& Fischel, supra note 5, at 426 (arguing the "duty of loyalty is a response to the impossibility of writing contracts completely specifying the parties' obligations").

407 Lonergan v. EPE Holdings L.L.C., 5 A.3d 1008, 1018 (Del. Ch. 2010).

408 Cf. Miller, supra note 4, at 140 (criticizing the bifurcated approach of the Model Business Corporation Act as "ill suited to the multiplicity of management structures housed in the LLC"). 
is the famous teaching case McConnell v. Hunt Sports Enterprises. ${ }^{409}$ A waiver can provide a seal of approval for a specific relationship planned between a member and the LLC. For example, a wholesaler organized as an LLC may plan to rent its warehouse from one of the investors. ${ }^{410}$ Or a businessperson that runs several LLCs in which they have also invested may do so through a management company. A waiver of the duty of loyalty can also be used to protect a managing member who also manages other LLCs from being exposed to unavoidable conflicts.

A waiver of the duty of care could be used to mitigate uncertainty over whether the business judgment rule or some higher standard will be applied. ${ }^{411}$ Parties may wish to address this uncertainty and leverage the nuances of existing case law by setting fiduciary duties to be equivalent to those that apply in corporation law. The Delaware Supreme Court upheld such a provision, for an LP agreement, in Gotham Partners. ${ }^{412}$ Parties may want to contractually protect themselves at the outset from an investor with a history of litigiousness. ${ }^{413} \mathrm{~A}$ waiver may be part of an agreement not to bring a claim over an earlier dispute. $^{414}$

A narrowly tailored waiver of fiduciary duties may also serve to protect management of an $\mathrm{L}_{3} \mathrm{C}^{415}$ organized to serve a social mission, as well as provide a return on investment, from liability for foregoing the highest possible financial returns in order to advance its social mission. Absent contractual or statutory protection, there is a risk that operating an LLC for a stated purpose other than to maximize member value may expose managing members to suit for breaching their fiduciary duties. This may be particularly worthwhile in

409 See McConnell v. Hunt Sport Enters., 725 N.E.2d 1193 (Ohio Ct. App. 1999) (enforcing an operating agreement in which the members had waived the duty of loyalty in order to secure the participation of a current investor in multiple professional sports franchises that might have been construed as competing with the LLC).

410 Cf. Hibbs v. Berger, 430 S.W.3d 296, 316-18 (Mo. Ct. App. 2014).

411 See Madden, supra note 36 (positing the law around fiduciary duties in "five major states"-Delaware, Massachusetts, California, New York, and Illinois-is much less clear for LLCs than for corporations).

412 See Gotham Partners, L.P. v. Hallwood Realty Partners, L.P., 817 A.2d 160, 163-64 (Del. 2002).

413 See, e.g., Kahn v. Icahn, No. CIV. A.15916, 1998 WL 832629, at *1 n.1 (Del. Ch. Nov. 12,1998 ) (noting that the defendant's brief identifies the plaintiffs as named plaintiffs in at least thirteen lawsuits alleging improper conduct).

414 See, e.g., USAT Reorganization L.L.C. v. Writer, No. D043230, 2004 WL 2538848, at *16 (Cal. Ct. App. Nov. 10, 2004).

415 “A 'low-profit limited liability company' (L3C) is a new, hybrid business form which can leverage foundations' program-related investments to access trillions of dollars of market-driven capital for ventures with modest financial prospects, but the possibility of major social impact." Marc J. Lane, L3Cs Hold Key to Solving State's Social Woes, CRAIN's CHI. Bus. (Aug. 9, 2008), http://www.chicagobusiness.com/article/20080809/ISSUE07/1000 30399 [https://perma.cc/QA3H-VC5V]. The addition of goals other than profit-maximization creates uncertainties as to the application of traditional models of fiduciary duty. 
states that do not have a constituency statute election. ${ }^{416}$ However, courts in those states may be leery of a contractual provision that attempts to perform the function of a constituency statute election that the legislature of that state has chosen not to enact. Even in states with constituency statute election, a narrowly tailored waiver of this sort could be used as an additional layer of protection.

In addition to this statutory uncertainty, the law of fiduciary obligation is "situation-specific." ${ }^{17}$ Thus, a broad ability to modify fiduciary duties allows parties to tailor fiduciary duties to meet their specific needs and circumstances. Potential active participants in an investment are very concerned about personal liability - hence the ubiquity of indemnity clauses in corporate bylaws, officers' and directors' insurance, and indemnity clauses in employment contracts. In addition, a party desiring to form an LLC in a state whose LLC act does not provide default fiduciary duties can reduce uncertainty by defining fiduciary duties in the operating agreement. The Supreme Court of Delaware has enforced a provision in an LP agreement applying the entire fairness standard to actions by the general partner in regards to the limited partners. ${ }^{418}$

Going beyond the value of the above, the ability to include such measures in the contract can be a powerful negotiation tool. A waiver might sufficiently assuage the concerns about personal liability of a party that would not otherwise participate in the LLC. Such a waiver may be the only avenue around deadlock over terms. Default fiduciary duties can lower the cost to negotiate, and the ability to opt out of those default terms can do the same. ${ }^{419}$ The traditional concern, that fiduciary duties are needed to protect a weak party from a party in a position of dominance, ${ }^{420}$ is not present at the time the bargain is struck. Typically, parties can walk away from the deal. If a weak party truly does need to be protected from a party in a position of dominance as a contractual relationship is being formed, then the contractual doctrine of unconscionability may apply. Fiduciary duties also shift risk to the managers of the company, increasing costs. ${ }^{421}$ A waiver can be a negotiated attempt to shift that risk

416 There are nineteen such states (including the District of Columbia) as of 2009: Alabama, Alaska, Arkansas, California, Colorado, Delaware, the District of Columbia, Kansas, Michigan, Mississippi, Montana, New Hampshire, North Carolina, Oklahoma, South Carolina, Texas, Utah, Washington, and West Virginia. See Anthony Bisconti, The Double Bottom Line: Can Constituency Statutes Protect Socially Responsible Corporations Stuck in Revlon Land?, 42 Loy. L.A. L. REV. 765, 768 n.13 (2009). Eight of those nineteen are test states discussed in this article. "Constituency statutes permit board members to consider nonshareholder interests when exercising their corporate decision-making authority." Id. at 767.

417 Deborah A. DeMott, Beyond Metaphor: An Analysis of Fiduciary Obligation, 1988 DUKE L.J. 879, 879 (1988).

418 Gotham Partners v. Hallwood Realty Partners, 817 A.2d 160, 167-68 (Del. 2002).

419 Frank H. Easterbrook \& Daniel R. Fischel, Close Corporations and Agency Costs, 38 Stan. L. REV. 271, 291 (1986).

420 See DeMott, supra note 417, at 915.

421 Eisenberg, supra note 10, at 249; see also Butler \& Ribstein, supra note 16, at 30 (positing that managers are poor risk-bearers); Kenneth B. Davis, Jr., Judicial Review of Fiduciary 
back to the investors in return for decreased compensation required by the managers.

A complete waiver of fiduciary duties does not quite create the kind of Wild, Wild West business environment the anti-contractarians have implied. ${ }^{422}$ Other protections exist for the parties, notably the implied covenant of good faith and fair dealing present in all contracts. ${ }^{423}$ The implied covenant is intended to provide a remedy for just the sort of nefarious skullduggery about which the anti-contractarians express so much concern, without being so overinclusive as to prevent bargained-for activities.

\section{MICRO IMPLICATIONS}

The substantial uncertainty due to very limited directly applicable case law and the lack of support for a clear analysis based on either the statutory text or by analogy to LP case law will have significant practical implications. Part A addresses implications for LLC litigation. Part B addresses implications for transaction planning.

\section{A. Litigation Consequences}

It should be expected that contractual provisions providing for the waiver of fiduciary duties will be held invalid in some of the test states discussed. This may be exacerbated by a certain amount of confusion over what exactly the applicable fiduciary duties are. Waivers may not be enforced due to judicial error or due to a judge hostile to contracting out of fiduciary duties - whether in general or in response to a "hard case" where it appears that one party has used the waiver to take advantage of a less sophisticated party.

For judges holding waivers of fiduciary duty invalid, there are two primary available paths of rationalization. First, judges may do so through their inter-

Decisionmaking - Some Theoretical Perspectives, 80 Nw. U.L. REv. 1, 27-29 (1985) (discussing the costs associated with fiduciary duties).

422 See, e.g., Miller, supra note 4, at 139 (referencing a "devil-may-care" standard (quoting Gelfman v. Weeden Inv'rs, L.P., 859 A.2d 89, 114 (Del. Ch. 2004))).

423 See Joseph M. Perillo, Calamari and Perillo on Contracts $\S 11.38$ (a), at 475 (5th ed. 2003) (citing Kirke La Shelle Co. v. Paul Armstrong Co., 188 N.E. 163, 167 (N.Y. 1933)); see also RESTATEMENT (SECOND) OF CONTRACTS $\$ 205 \mathrm{cmt}$. a, d (AM. LAW INST. 1981) ("Good faith performance or enforcement of a contract emphasizes faithfulness to an agreed common purpose and consistency with the justified expectations of the other party; it excludes a variety of types of conduct characterized as involving 'bad faith' because they violate community standards of decency, fairness or reasonableness. ... Subterfuges and evasions violate the obligation of good faith in performance even though the actor believes his conduct to be justified. But the obligation goes further: bad faith may be overt or may consist of inaction, and fair dealing may require more than honesty. ... [T] he following types [of bad faith] are among those which have been recognized in judicial decisions: evasion of the spirit of the bargain, lack of diligence and slacking off, willful rendering of imperfect performance, abuse of a power to specify terms, and interference with or failure to cooperate in the other party's performance."). 
pretation of the applicable LLC statute. A vague statute (e.g., Colorado's) or an ambiguous statute (e.g., California's) will allow a court to argue that principles of common law should be applied. They can then rely on this interpretation to hold a waiver void as against public policy or ineffective. Second, judges may rely on contract interpretation to hold waivers of fiduciary duty invalid. For example, they may read fiduciary duties into an LLC operating agreement where they should not be under the objective theory of contract. Alternatively, they may read a provision that should effectively waive fiduciary duties in an overly narrow manner so as to not apply to the specific facts before the court. Given the expected bias against waivers of fiduciary duties, even judges unwilling to openly hold such provisions ineffective are more likely to construe them narrowly. An example may be a waiver of the duty of loyalty; the duty of disclosure is a component of the duty of loyalty, ${ }^{424}$ but a court may be tempted to find that a straightforward waiver of the "duty of loyalty" does not also waive the duty of disclosure. ${ }^{425}$

Courts may construe the implied contractual covenants of good faith and fair dealing broadly in order to defeat an attempt to waive fiduciary duties. ${ }^{426} \mathrm{~A}$ judge sympathetic to the plaintiff may wrongly interpret the implied covenant of good faith to prohibit self-dealing. ${ }^{427}$ However, Delaware courts have clearly stated that "[a] party does not act in bad faith by relying on contract provisions for which that party bargained where doing so simply limits advantages to another party." 428

Courts hostile to fiduciary duty waivers may also use procedure to avoid having to apply substantive law with which they disagree. Choice of law provisions might be defeated through manipulation of conflicts of law doctrine. Derivative suits might be found to fail standing requirements. ${ }^{429}$ There is a danger of a court applying the public policy of its state to avoid enforcing a waiver un-

\footnotetext{
424 See Stephen M. Bainbridge, Agency, Partnerships \& LLCs 146 (2004) ("[A]n obligation to disclose material facts is part and parcel of the duty of loyalty.").

425 But see Ledford v. Smith, 618 S.E.2d 627, 636 (Ga. Ct. App. 2005) (holding that the member had no duty to disclose a business opportunity because the duty of loyalty had been waived and the action did not fall into the direct competition caveat in the waiver).

${ }^{426}$ But see Cincinnati SMSA Ltd. P'ship v. Cincinnati Bell Cellular Sys. Co., 708 A.2d 989, 991-94 (Del. 1998) (stressing the covenant of good faith has only a very narrow scope).

427 See Miller, supra note 8, at 597 (citing RoBert A. Hillman, The Richness of CONTRACT LAW 145 (1997) (arguing that the covenant of good faith embeds "community standards" in contracts)). But see Lonergan v. EPE Holdings L.L.C., 5 A.3d 1008, 1018 (Del. Ch. 2010) ("When an LP agreement eliminates fiduciary duties as part of a detailed contractual governance scheme, Delaware courts should be all the more hesitant to resort to the implied covenant.").

428 Nemec v. Shrader, 991 A.2d 1120, 1128 (Del. 2010).

429 See, e.g., Morris v. Hennon \& Brown Props., L.L.C., No. 1:07CV780, 2008 WL 2704292, at *4-6 (M.D.N.C. July 3, 2008) (finding a lack of standing and refusing to predict whether a North Carolina state court would enforce the waiver in question).
} 
der another state's laws. ${ }^{430}$ A federal court may cite a lack of state court precedent in refusing to enforce a waiver ${ }^{431}$ or even to broach the issue. ${ }^{432}$

The increased likelihood that a waiver will not be enforced encourages a party that has borne the brunt of shifting circumstances to litigate rather than renegotiate. ${ }^{433}$ Normally this party might best be able to address changed circumstances by negotiating with the other parties to redefine their relationship, perhaps modifying contractual fiduciary duties to reflect a new, weakened position. The possibility of an escape from the benefit of the bargain through litigation, however, limits how much the weakened party will be willing to pay for a renegotiated deal. This could create a hold-up problem leading to an otherwise value-added transaction being scuttled because one party feels that they can expect more from litigation than from any negotiated agreement. The uncertainty of enforcement of a waiver can also increase the probability of litigation. Parties with drastically different estimates of their ability to prevail in court will be unlikely to renegotiate successfully.

It is likely that the development of case law in this area will be stifled and only grow very slowly due to a limited number of cases and, in particular, binding precedent. Many operating agreements, particularly for the types of complex LLCs most likely to take advantage of the ability to contract around default rules, may be interpreted by courts outside of the state in which the LLC was formed ${ }^{434}$ or by federal courts. ${ }^{435}$ This diffuse pattern of litigation will diminish the reach of individual decisions unless decided by the highest court of the state. Parties will be unwilling to bargain for a waiver of fiduciary duties $e x$ ante due to uncertainty over the enforceability of such provisions faced with hostile courts, ambiguous statutes, or both, thus leaving no waiver to be analyzed in future litigation. Courts in states that do not define fiduciary duties by statute can be expected to be called upon regularly to decide what fiduciary duties apply to an LLC, at the same time building case law on what may or may not be construed as an effective waiver. Courts in states that set default fiduciary duties, on the other hand, are less likely to be asked to apply fiduciary duties in conjunction with LLC operating agreements. This delay is a matter of

430 See Merrick v. Cummin, 919 A.2d 495, 498 n.3 (Conn. App. Ct. 2007) (enforcing a waiver of fiduciary duties but applying Connecticut law to a Delaware corporation under a "fundamental policy" exception).

431 See, e.g., In re Allentown Ambassadors, Inc., 361 B.R. 422, 461 (E.D. Pa. 2007) (relying on North Carolina corporate law to predict that a North Carolina state court would not enforce the waiver in question).

432 See, e.g., Morris, 2008 WL 2704292, at *4-6 (finding a lack of standing and refusing to predict whether a North Carolina state court would enforce the waiver in question).

433 See Lonergan v. EPE Holdings L.L.C., 5 A. 2d 1008, 1018 n.4 (Del. Ch. 2010) (noting that relational contracts - such as an LP agreement or LLC operating agreement-provide abundant opportunity for renegotiation).

434 See, e.g., Kira, Inc. v. All Star Maint., No. A-03-CA-950 LY, 2006 WL 2193006, at *56 (W.D. Tex. July 31, 2006) (interpreting Nevada law).

435 See, e.g., Armour et al., supra note 390, at 610 (examining empirical evidence showing Delaware state courts losing litigation "market share," in particular to federal courts). 
some concern; the law of business associations cannot evolve without the development of case law. ${ }^{436}$

\section{B. Transaction Planning Considerations}

The other significant concern is that the uncertainty over the enforceability of waivers of fiduciary duty will lead planning attorneys to advise against what would otherwise be value added contractual terms relieving the parties of their fiduciary duties. Another consideration is that due to the paucity of case law in this area, a court from another state may have to apply the law of the state in which the LLC is incorporated without the benefit of precedent. Even after that decision, there would be no binding precedent in the state of incorporation because the only application of its law was by a court in another state. Even where precedential case law exists, the multiple avenues available to a court seeking to avoid enforcing a waiver of fiduciary duties leave enforcement of a waiver under consideration uncertain.

Businesspeople thrive on certainty and will avoid contracting for terms that add uncertainty into their businesses. In a handful of states-Delaware, Georgia, Kansas, Louisiana, Missouri, Nevada, North Carolina, and Texasplanning attorneys can rely on positive LLC precedents. Even in states with mixed precedents - Connecticut and Massachusetts - and in states without onpoint precedent, forcing a planning attorney to rely on the statutory languageAlabama, Arkansas, Colorado, Kentucky, Maine, Maryland, Michigan, Mississippi, New Hampshire, New Mexico, Washington, and Wisconsin - the business needs of the parties can be met by a well-tailored waiver that will capture the bargain of the parties while avoiding unnecessary language that might lead a court to void an entire provision. The Colorado LLC statute only makes very limited allowances for waiver.Parties can seek jurisdiction in what they perceive to be a friendly venue, either by incorporating the LLC in the chosen state or through a choice of law provision in the operating agreement. States that prove hostile to waivers of fiduciary duty can be expected to lose "market share" in the competition for LLC filings to states more friendly to contractually defined relationships. Parties can also attempt to address limitations on waivers through other provisions of the operating agreement. ${ }^{437}$

436 See Ribstein, supra note 3, at 33 ("The evolution of business associations depends on the development of case law and interstate acceptance of new terms."); see also id. at 102 ("[T]he value of business association statutes reflects the network consisting of materials such as cases, legal forms, treatises-that assists in interpretation and application of these statutes.").

${ }^{437}$ For example, by complementing an exculpatory provision in a state only expressly allowing such a provision with a provision limiting remedies to monetary damages. 


\section{CONCLUSION}

State laws can create a business environment more conducive to investment by entrepreneurs in new ventures by providing certainty and flexibility. To this end, waivers of fiduciary duties by LLC members should be broadly and clearly allowed. Courts should give parties to a contract the benefit of the bargain of that contract. Courts should enforce contracts both good and bad (or, perhaps a better way to state it: courts should not make judgments regarding whether a contract is "good" or "bad"). Doing so will better address the interests in businesspersons in forming LLCs and better effect the intent of legislatures in providing for the formations of LLCs. In the states without relevant case law, courts can send a strong positive message to the business community by enforcing a waiver of fiduciary duty when the question arises. Courts interpreting the law of states with negative precedent or relying on precedent from other entity forms would be well served by taking a closer look at the relevant LLC act. 
